\title{
UNIVERSITYOF
}

FORWARD

THINKING

WESTMINSTER用

WestminsterResearch

http://www.westminster.ac.uk/westminsterresearch

The role of GPS-enabled information in transforming operational decision making: an exploratory study

Habjan, A., Andriopoulos, C. and Gotsi, M.

This is an author's accepted manuscript of an article published in the European Journal of Information Systems, 23 (4), 481-502, 2014.

The final publication is available at Springer via:

https://dx.doi.org/10.1057/ejis.2014.2

The WestminsterResearch online digital archive at the University of Westminster aims to make the research output of the University available to a wider audience. Copyright and Moral Rights remain with the authors and/or copyright owners.

Whilst further distribution of specific materials from within this archive is forbidden, you may freely distribute the URL of WestminsterResearch: ((http://westminsterresearch.wmin.ac.uk/)).

In case of abuse or copyright appearing without permission e-mail repository@westminster.ac.uk 


\title{
The role of GPS-enabled information in transforming operational decision-making: An exploratory study
}

\begin{abstract}
Although the impact of ICT-enabled information on firm performance has been well documented in the business value of IT literature, our understanding of how GPS adoption can transform operational decision-making and foster differential firm performance is limited. In response, we conduct an exploratory comparative case study of three transport firms that have implemented the same GPS during the same year in their operations. Our results highlight that increased use of GPS-enabled information can enhance information quality and make operational decision-making more fact-based and collaborative. We also find that such transformations in operational decision-making, driven by increased use of GPS-enabled information, can foster differential performance impacts. However, we warn scholars and practitioners that a firm's information management capability (in terms of availability of quality information in decision-making, software tools for connectivity and access to information, IT systems integration post-GPS adoption and adaptability of the infrastructure to emerging business needs) and organizational factors (such as such as top management support, project management of GPS implementation, financial support, end-user involvement, rewarding, training and employee resistance) can facilitate (or inhibit) effective use of GPS-enabled information in operational decision-making and, thus, moderate differential performance benefits of GPS adoption.
\end{abstract}

Keywords: Business value of IT, Operational decision-making, GPS adoption, Information management capability, Organizational Factors, Performance, Case Study 


\section{The role of GPS-enabled information in transforming operational decision-making: An exploratory study}

\section{Introduction}

The potential of information systems (IS) to transform decision-making and foster organizational performance has been emphasized in the business value of IT literature for quite some time (Dedrick et al., 2003; Mithas et al., 2011). In supply chain studies, IS have been found to support timely decisions, provide information that enhances comparative advantage in supply chain relationships, help to manage risk in exporting and offer a means to cope with uncertainty inherent in the business environment (White et al., 2003; Eng, 2004; Souchon et al., 2004; Li \& Lin, 2006; Davis \& Golicic, 2010). High quality information, i.e. information that is reliable, accurate and timely (Low \& Mohr, 2001; Davis \& Golicic, 2010), facilitates improvements in decision quality and can, in turn, foster improvements in firm performance (Parssian, 2006). To leverage the benefits of high quality information, firms are, therefore, increasingly investing in Information and Communication Technology (ICT). ICT enables storing, organizing and structuring information consistent with user needs and endorses instantaneous information availability through easy sharing (Carbonara, 2005).

In transport firms, the application of ICT is particularly critical in supporting operational decision-making and enhancing firm performance. Unexpected delays, lack of coordination, delivery constraints and variable demand are common obstacles in providing superior customer value in this industry (Sanchez-Rodrigues et al., 2008). Practical evidence shows that transport firms with little access to high quality information find it hard to manage transport service amidst such uncertainty. For example, they find difficulty in monitoring employees' daily productivity, struggle to exercise control over speeding (e.g. $5 \mathrm{mph}$ driven above the posted speed limit can cost about 20 cents more per gallon of gas) and often fail to identify the location of every vehicle, to send the closest vehicle to a job site, and so forth. Such uncertainty amplifies exposure to risk in the supply chain and leads to increased total costs (Sanchez-Rodrigues et al., 2008). The need to inform operational decision-making with high quality information is, therefore, extremely important in the transport industry (SanchezRodrigues et al., 2008; Sanchez-Rodrigues et al., 2010a).

In response, investments in automatic vehicle location technologies such as Global Positioning System (GPS) have been wide spread in the transport industry. GPS carries the promise of improving driver, vehicle and overall firm performance, by enhancing 
communication, planning and agility in the transport process (Van Der Vorst et al., 1998; Giannopoulos, 2004; Marchet et al., 2009). GPS technology has some important and interesting characteristics. It allows transport firms to determine the geographical position of a vehicle on a map in real time, calculates the distance to a transport destination, enables communication between dispatchers and drivers at all times and collects transport data that can be used for further analysis (Mintsis et al., 2004). GPS-enabled information can, therefore, potentially aid transport firms in minimizing costs and improving control in the transport process, calculating wages, reducing manual work and the use of mobile phones, automating and improving information sharing, and, ultimately, optimizing real-time decision-making, fleet management and customer service (Giannopoulos, 2004; Mintsis et al., 2004; Marchet et al., 2009).

However, scholars increasingly argue that leveraging such performance benefits, depends less on having the technology and more on being able to make the best use of information in decision-making (Dedrick et al., 2003). Studies on the relationship between investments in ICT and firm performance have produced equivocal findings (Davis \& Golicic, 2010). ICT investments have been linked to improvements in processes and operations (Ryssel et al., 2004; Davis \& Golicic, 2010; Mithas et al., 2011), productivity (Brynjolfsson, 1993; Dedrick et al., 2003), financial performance (Devaraj \& Kohli, 2000), efficiency and relationship development (Wu et al., 2003), competitiveness (Liu \& Arnett, 2000; Mithas et al., 2011) and customer satisfaction (Tracey et al., 1999; Ata \& Toker, 2012). Yet, critics of studies linking ICT investments to firm performance note that firms only enjoy differential performance when ICT is combined with resources and capabilities that drive comparative advantage (Clemons \& Row, 1991; Mithas et al., 2011). Scholars, for instance, have highlighted the role of systems integration (Rai et al., 2006), alignment with core competencies and the firm's information management capability (Mithas et al., 2011) as critical in leveraging differentials in firm performance. It seems that some firms use IT more productively than others (Dedrick et al., 2003). Emphasis is, therefore, increasingly placed on the underlying mechanisms that link investments in ICT to financial performance (Bharadwaj, 2000).

Despite increasing recognition of the value that GPS investments can bring to transport firms and their wide spread adoption in the transport industry, our understanding of how GPS-enabled information transforms operational decision-making in this context and how it can positively impact firm performance remains scarce (Mukhopadhyay et al., 1997; 
Bharadwaj, 2000; Dedrick et al., 2003; Lu \& Ramamurthy, 2011). To address this gap, we conducted a comparative case study of three transport firms that adopted the same GPS during the same year. We explored: (RQ1) How does the adoption of GPS transform operational decision-making in the transport process? (RQ2) What are the underlying mechanisms that facilitate better use of GPS-enabled information in operational decision-making and link investments in GPS to firm performance?

Our contribution to the business value of IT literature is threefold. Firstly, our results highlight that GPS-enabled information can enable a shift towards fact-based and collaborative decision-making in the supply chain (among the transport firm, client, maintenance firm etc.). Secondly, we find that the more prominent these changes in operational decision-making are, the more they can underlie differential performance impacts of GPS adoption. Yet, thirdly, we identify that the firm's information management capability (availability of quality information in decision-making, software tools for connectivity and access to information, IT systems integration post-GPS adoption and adaptability of the infrastructure to emerging business needs) and organizational factors (such as top management support, project management of GPS implementation, financial support, enduser involvement, rewarding, training and low employee resistance) endorse more effective use of GPS-enabled information in operational decision-making and, therefore, moderate the relationship between GPS-enabled information and firm performance. As such, GPS-enabled information has the power to not only allow firms to automate (replace human labour in automating business processes) and informate (provide information about business activities to senior management and employees), but more importantly to transform information quality and operational decision-making in supply chain relationships (Zuboff, 1988).

The remainder of this paper is organized as follows. We firstly review literature on the business value of IT and operational decision-making. More specifically, we examine extant studies on the impact of information sharing and data-driven operational decision-making on process outcomes and firm performance, and develop our research questions. We then outline the research approach followed in this study. We introduce the three case transport firms, outline the sources of data and explain our data analysis procedure. This is followed by our findings on how GPS transforms operational decision-making in the transport process and the underlying mechanisms that link GPS-enabled information to improvements in firm performance. In the discussion section, we explore the theoretical contributions and 
managerial implications of our findings. The paper concludes with avenues for future research.

\section{Theoretical Background}

The inherent uncertainty in the transport process is a key challenge for operational decisionmaking in transport supply chains. Uncertainty is seen to increase risk within supply chains and is an obstacle to the effective management and control of supply chain operations (Sanchez-Rodrigues et al., 2010a). Generally, "uncertainty occurs when decision makers cannot estimate the outcome of an event or the probability of its occurrence" (SanchezRodrigues et al., 2010b, p. 62). With limited information at hand, decision makers find it hard to determine how they should proceed and which decision is best to accept (Van Der Vorst \& Beulens, 2002). In the transport industry, uncertainty comes in different forms. Request uncertainty, for instance, refers to spontaneous changes of the portfolio of requests (Fleischmann et al., 2004). Handling uncertainty refers to issues pertaining loading or unloading times; these may exceed or be shorter than the planned handling time. Transshipment uncertainty relates to possible delays caused by the non-availability of ramps, gates, or special loading or unloading equipment, such as forklift (Schönberger, 2010). Lastly, loading uncertainty refers to situations when different types of goods cannot be loaded as planned or are not allowed to be loaded by the same resource (Gendreau et al., 2004).

Amidst these different types of uncertainty, the availability of information has been highlighted in the literature as a catalyst that can improve decision-making and positively influence firm performance (Vandenbosch \& Huff, 1997; Souchon et al., 2004; Li et al., 2009; Popovič et al., 2012; Tambe et al., 2012). Tambe et al. (2012), for instance, find that firms that engage in data-driven decision-making enjoy a higher output and productivity return and also see benefits in asset utilization, return on equity and market value. They, therefore, argue that IT investments that endorse the collection and distribution of valuable information should lower costs and improve firm performance. For example, utilization of technology can help to shorten lead times and simplify orders (Van Der Vorst et al., 1998). Companies that use quality information have a better understanding of their internal operations and achieve work of better quality (Petter et al., 2008). However, to generate improvements in organizational performance, information must be of good quality and support decision-making (Vukšić et al., 2013) in processes that add value to the firm (Davenport \& Beers, 1995). Researchers from different domains have deliberated about what 
can be classified as 'good information' for quite some time (Eppler et al., 2004). A review of management, communication and IT literature on what determines information quality, reveals numerous criteria that influence information quality in different contexts (Eppler, 2006). It is, therefore, fair to say that information quality is a vaguely defined concept (Lillrank, 2003) and there is no single established definition for it (Ruževičius \& Gedminaitè, 2007). For the purpose of this work, we adopt the definition of information quality offered by Ruževičius and Gedminaite (2007). We argue that information quality is a function of its reliability, accuracy and timeliness (Low \& Mohr, 2001) and focus on information that serves the needs of dispatchers, who are planning and controlling operations in dispatching centers within transport firms (Mintsis et al., 2004).

Quality information can particularly facilitate operational decision-making in the transport industry. Operational decision-making includes areas such as the fine-tuning of production, sales and distribution and the management of day-to-day operating processes and systems (McDonald et al., 2008). In the transport industry, operational decision-making refers to "decision making performed by local management, yard masters and dispatchers, for example, in a highly dynamic environment, where the time factor plays an important role and detailed representations of vehicles, facilities and activities are essential. It includes: the implementation and adjustment of schedules for services, crews, and maintenance activities; the routing and dispatching of vehicles and crews; the allocation of scarce resources" (Crainic, 2000, p. 274). Information enters the decision-making process when the decision makers identify a problem, develop criteria, and formulate a range of possible solutions to the problem (Korhonen-Sande, 2010). In decision-making, the use of information can be either instrumental (direct), where a decision is made through the direct application of the information, or conceptual (indirect), where information is used in the form of concepts, assumptions, models, theories and heuristics (rules of thumb) (Korhonen-Sande, 2010, p. 662). Under conditions of high uncertainty (Citroen, 2011), high complexity and high time pressure (Low \& Mohr, 2001) information has been found to act as a catalyst that supports decision-making. Quality information from electronic and real-time data, for instance, has been found to enhance real-time analysis in decision-making (Mithas et al., 2011), enable quick responses to market needs (Davis \& Golicic, 2010) and, overall, improve supply chain logistics efficiency (Paulraj \& Chen, 2007).

To acquire such information and mobilize its benefits, transport firms invest increasingly in ICT. This includes technologies for communication and information exchange 
between organizations and individuals (Morgan et al., 2006, p. 980), such as automatic vehicle location technologies using either GPS or digital mobile communications (Giannopoulos, 2004). Reported benefits include improved real-time tracking information, better information visibility and reliability and enhanced up to date information sharing (Ferneley \& Ben, 2006; Morgan et al., 2006). The increased use of easily accessible, highly accurate and on-time information, therefore, enhances a firm's information management capability and facilitates improvements in operational decision-making (White et al., 2003). For example, for firms with substantial export operations, increasing use of information helps them avoid making 'not optimal' export decisions (Souchon et al., 2003). Additionally, firms can use information to understand and manage the performance of their marketing strategies (Moorman, 1995). Moreover, increased use of information has been found to improve confidence in the decision-making process, since it equips managers with the ability to deal with ambiguous situations more effectively (White et al., 2003).

The impact of IT on business processes and firm performance has dominated debate in the business value of IT literature (Brynjolfsson \& Hitt, 1996; Kohli \& Devaraj, 2003; Melville et al., 2004; Mithas et al., 2011). Several studies have taken a process orientation to illustrate the positive performance impact of IT (Mukhopadhyay et al., 1997). Mukhopadhyay et al. (1997), for instance, argue that IT can improve the efficiency and effectiveness of processes in terms of cost and quality, making IT investments economically valuable. IT enables retailers and manufacturers to track inventory levels and availability of raw materials (Davis \& Golicic, 2010). IT can also improve communication and aid dynamic pricing in supply chains (Li \& Lin, 2006; Li et al., 2009). Scholars, thus, support that IT investments can improve process efficiency and effectiveness (Karimi et al., 2007), productivity (Brynjolfsson, 1993; Dedrick et al., 2003), relationship development (Wu et al., 2003), customer satisfaction (Tracey et al., 1999; Ata \& Toker, 2012), competitiveness (Liu \& Arnett, 2000; Mithas et al., 2011) and, ultimately, financial performance (Devaraj \& Kohli, 2000). Yet, critics of studies linking IT investments to firm performance differentials argue that some firms use IT more productively than others (Dedrick et al., 2003) and, thus, IT infrastructure per se will not necessarily improve firm performance relative to competitors (Mithas et al., 2011). For instance, Kettinger et al. (1994) show a negative relationship between IT adoption and market share and profits, Hitt and Brynjolfsson (1996) offer mixed results in analyses of correlations between IT spending and various measures of business profitability, while Ryssel et al. (2004) report that IT has no effect on relationship value. 
Mithas et al. (2008) also propose an insignificant or negative relationship between IT investments and customer satisfaction.

Against these equivocal findings, there is, therefore, growing evidence that although IT infrastructure provides a needed foundation for decision-making, it is the use and management of information that are critical, so that technology-enabled information can be appropriately deployed to generate differentials in firm performance (Mukhopadhyay et al., 1997; Mithas et al., 2011). Scholars, for instance, argue that "the ability to provide data and information to users with the appropriate levels of accuracy, timeliness, reliability, security, confidentiality, connectivity, and access and the ability to tailor these in response to changing business needs and directions" (Mithas et al., 2011, p. 238), i.e. a firm's information management capability, may enable process management that can trigger differences in firm performance (Kohli \& Grover, 2008). This includes not only the availability of quality information for decision-making, but also software tools that endorse connectivity and access to such information, IT systems integration and the ability to adapt the IT infrastructure to emerging business needs (Mithas et al., 2011). A number of scholars studying supply chains also highlight the role that information sharing plays on mobilizing positive process outcomes and firm performance (Mukhopadhyay et al., 1997; Mukhopadhyay \& Kekre, 2002). Information sharing enables processes that connect the firm with its supply chain business partners (Davenport, 1993). As such, it enhances internal business process integration and improves a firm's ability to rapidly cope with market or demand changes (Lu \& Ramamurthy, 2011). Mukhopadhyay \& Kekre (2002), for instance, show that electronic integration in B2B procurement processes offers suppliers operational gains in transaction processing, which over time translate into strategic benefits, such as increased sales. Improved inventory turnover, plant productivity, product quality, accuracy and sales, along with reduced costs, are often highlighted as key productivity impacts of information sharing (Dedrick et al., 2003).

In addition, writings focusing on IT-organization fit highlight various critical organization factors for successful IT adoption (Oh \& Pinsonneault, 2007; McLaren et al., 2011). Nah et al. (2001), for instance, emphasize top management support, a business plan and clear vision, along with effective communication, as important organizational factors. Leung (2001) also argues that organizational structure and design, organizational culture and human resource management, as well as communication, employee satisfaction and motivation can influence successful IT adoption. Moreover, Hong and Kim (2002) claim that IT implementation success depends largely on the level of IT and process adaptation, as well 
as on the extent of organizational resistance. Similarly, Dezdar and Sulaiman (2011) show a positive relationship between organizational factors such as top management support, enterprise-wide communication and IT training and education, and IT implementation success. Top management should have an active role in the IT adoption process ((Nah et al., 2001; Dezdar \& Sulaiman, 2011). Moreover, IT needs to be integrated into the firm's strategic planning process (Tippins \& Sohi, 2003). Additionally, formal training should be provided to help end-users accept the organizational change (Nah et al., 2001); it should address all aspects of the system and be offered on a continuous basis (Dezdar \& Sulaiman, 2011). Finally, enterprise-wide communication is important, since expectations for IT adoption should be clearly communicated across levels (Nah et al., 2001; Dezdar \& Sulaiman, 2011).

Building on this theoretical background, our understanding of how GPS-enabled information transforms operational decision-making in the transport industry to support decisions amidst high uncertainty remains limited. Moreover, against the equivocal findings on the relationship between investments in ICT and financial performance (Davis \& Golicic, 2010), our knowledge of the underlying mechanisms that link GPS-enabled information to improvements in firm performance is also scarce (Bharadwaj, 2000; Dedrick et al., 2003). These gaps have motivated our research questions: (RQ1) How does the adoption of GPS transform operational decision-making in the transport process? (RQ2) What are the underlying mechanisms that facilitate better use of GPS-enabled information in operational decision-making and link investments in GPS to firm performance? Our research explores these questions through a comparative case study of three transport firms that have implemented the same GPS during the same year. We now detail our research approach.

\section{Research approach}

Because of the early stages of research on how information stemming from GPS adoption may transform operational decision-making and improve firm performance, we adopted an exploratory case study method (Benbasat et al., 1984). Case studies provide a source of well grounded, rich descriptions and explanations of processes (Miles \& Huberman, 1994) that are relatively poorly understood (Glaser \& Strauss, 1967). In this study we employed a multi-case design that supports a replication logic, whereby a set of cases are treated as a series of experiments, each serving to confirm or disconfirm a set of observations (Yin, 1994). 


\begin{tabular}{|c|c|c|c|c|c|}
\hline Firm & $\begin{array}{l}\text { Year } \\
\text { founded }\end{array}$ & $\begin{array}{l}\text { Services and } \\
\text { specialization }\end{array}$ & $\begin{array}{l}\text { Number of } \\
\text { employees }\end{array}$ & $\begin{array}{l}\text { Annual } \\
\text { revenues }\end{array}$ & $\begin{array}{l}\text { Number of } \\
\text { vehicles }\end{array}$ \\
\hline Firm A & 1978 & $\begin{array}{l}\text { Land transport in EU } \\
\text { of all types of goods } \\
\text { using road trains and } \\
\text { mega trailers, } \\
\text { maintenance }\end{array}$ & 61 & $€ 5,718,735$ & 45 \\
\hline Firm B & 1986 & $\begin{array}{l}\text { Land transport in EU } \\
\text { of frozen food and } \\
\text { liquids, using } \\
\text { specialized vehicles } \\
\text { for food and liquids } \\
\text { transportation } \\
\end{array}$ & 54 & $€ 2,745,945$ & 39 \\
\hline Firm C & 1990 & $\begin{array}{l}\text { Land transport in EU } \\
\text { of all types of goods } \\
\text { using road trains and } \\
\text { mega trailers, } \\
\text { maintenance }\end{array}$ & 117 & $€ 15,960,277$ & 69 \\
\hline
\end{tabular}

Research sites

We carried this research in transport firms, as the transport context has proven well suited to study the benefits of information on decision-making (Mintsis et al., 2004). Uncertainty in costs, routes and dealing with distributors are challenging decision-making in transportation (Ghodsypour \& O'brien, 2001). We theoretically sampled firms to fit our research focus (Eisenhardt, 1989). The three Slovenian medium-sized (according to the European Commission, firms with 50-250 employees are classified as medium-sized) transport firms have all implemented the same GPS during the same year. Since its adoption they have grown in size, annual revenues and size of fleet. The transport industry in Slovenia represents almost 10 percent of the Gross Domestic Product and is the only industry in the country that has significantly grown in the past two years (by over 10 percent). Lastly, within this setting we sought firms with similarities that would aid comparisons and replication, yet with sufficient heterogeneity to help assess potential generalizability. Table 1 provides relevant details about the three transport firms in our study.

\section{Table 1 Overview of case firms}

Source: The Agency of the Republic of Slovenia for Public Legal Records and Related Services

\section{Data collection}

We carried out this research using qualitative methods from multiple sources (Eisenhardt, 1989). Data were collected from three main sources (see Table 2): (1) semi-structured interviews, (2) archival data, and (3) observation. Interviews were our primary source of inductive data, while archival data and observations extended our understandings of each case context and added depth to our interview findings (Forster, 1994). 
Table 2 Data sources

\begin{tabular}{|c|c|c|c|}
\hline Firm & $\begin{array}{l}\text { Source } 1 \text { - Semi structured } \\
\text { interviews }\end{array}$ & $\begin{array}{l}\text { Source } 2 \text { - Firms' archival } \\
\text { data }\end{array}$ & $\begin{array}{l}\text { Source 3 - Office and field } \\
\text { observation }\end{array}$ \\
\hline \multirow[t]{2}{*}{ Firm A } & $\begin{array}{l}\text { General manager (3) } \\
\text { Quality assurance manager (1) } \\
\text { Logistics manager (2) } \\
\text { Dispatcher (5) } \\
\text { Administrator (1) } \\
\text { Client (5) }\end{array}$ & $\begin{array}{l}\text { Annual financial reports } \\
\text { Customer satisfaction } \\
\text { surveys } \\
\text { Annual management review } \\
\text { reports } \\
\text { GPS booklets } \\
\text { Transport reports }\end{array}$ & $\begin{array}{l}\text { Office and vehicle } \\
\text { observation }\end{array}$ \\
\hline & Total (17) & Total: approx. 250 pages & Total: approx. 1.5 months \\
\hline \multirow[t]{2}{*}{ Firm B } & $\begin{array}{l}\text { General manager (3) } \\
\text { Logistics manager (2) } \\
\text { Dispatcher (4) }\end{array}$ & $\begin{array}{l}\text { Quality manual } \\
\text { GPS instructions and } \\
\text { booklets } \\
\text { Process instructions } \\
\text { Periodical financial reports } \\
\text { Transport reports }\end{array}$ & $\begin{array}{l}\text { Office and vehicle } \\
\text { observation }\end{array}$ \\
\hline & Total (16) & Total: approx. 200 pages & Total: approx. 3 weeks \\
\hline \multirow[t]{2}{*}{ Firm C } & $\begin{array}{l}\text { General manager (3) } \\
\text { Transport manager (1) } \\
\text { Dispatcher (3) } \\
\text { Client (6) }\end{array}$ & $\begin{array}{l}\text { Annual financial reports } \\
\text { Annual management review } \\
\text { reports } \\
\text { Quality manual } \\
\text { Process instructions } \\
\text { GPS booklets } \\
\text { Transport reports }\end{array}$ & $\begin{array}{l}\text { Office and vehicle } \\
\text { observation }\end{array}$ \\
\hline & Total (13) & Total: approx. 400 pages & Total: approx. 1 month \\
\hline
\end{tabular}

Interviews. We conducted a total of 28 interviews with employees who were directly (e.g. Dispatchers) and indirectly (Administrators) involved in the transport process. We also sought information from clients. We conducted 18 interviews with clients who used the transport services of the case firms. Interviews were conducted from December 2009 to January 2010, and in May 2011. Their length varied from one hour to one hour and a half (average length was one 70 minutes). Interviews were audio recorded and transcribed.

Archival data. Annual financial reports, GPS handbooks, transport reports, quality manuals and process instructions were the main internal documents that were examined. All three firms have also implemented quality standard ISO 9001. Therefore, quality manuals and process flows were also examined.

Field observation. Over three months, from December 2009 to February 2010 we recorded how dispatchers used GPS when organizing transport, how the drivers in the vehicles used 
GPS and how information available through GPS was transmitted to other departments for further use.

\section{Data analysis}

Our data analysis was iterative. Following Glaser and Strauss (1967) and Miles and Huberman (1994), systematic, iterative comparisons of data, emerging categories and existing literature aided the development of an integrative theoretical framework.

Stage 1: Isolating broad categories within each case. From our data, we first compiled separate case studies of each firm. We identified patterns and variance in descriptions of how information stemming from GPS adoption transformed operational decision-making and examined the underlying mechanisms that linked GPS-enabled information to improvements in firm performance. To assess the reliability of the generated open codes, we then involved a second coder, with considerable qualitative research experience. Disagreements were resolved through discussion between the first author and second coder.

Stage 2: Linking related concepts within each case. During this stage we examined all conclusions derived from the initial coding and established links between and among previously stated categories, a process known as selective coding. We allowed concepts and patterns to emerge based on the primary data collected, while new categories were added and others were regrouped when further interviews were analyzed (Cassell \& Symon, 1994).

Stage 3: Cross case comparisons. To enhance generalizability (Firestone \& Herriott, 1983), as well as to deepen understanding and explanation (Glaser \& Strauss, 1967), we compared each category and its properties across cases. Our main intent was to compare and contrast changes in the operational decision-making amongst the three case firms. To assess the reliability of each dimension we firstly involved the second coder. All disagreements were resolved through discussion. Secondly, we shared the results of the initial analysis with key informants at the three case firms and with an independent professional in the field to assess whether the conclusions reached were plausible.

Stage 4: Connecting emergent themes and ideas with the theoretical concepts of the literature. Our data analysis moved back and forth between the emerging themes and extant literature to explore broadly possible explanations for our findings and enable focus on the explanation that best fit with the data; what Yin (2003) called explanation building. 
Due to space limitations, we introduce how the three case firms used GPS in their transport process in our supplementary online Appendix. We now discuss our findings. We first reveal how the the adoption of GPS has transformed operational decision-making in the three firms (RQ1). Second, we uncover the underlying mechanisms that link GPS-enabled information to improvements in firm performance (RQ2).

\section{Findings}

Changes in operational decision-making after GPS adoption

In response to our first research question, we examined how information stemming from GPS adoption transformed operational decision-making in the three case firms. We found that use of GPS mobilized improvements in information quality across the case firms. Moreover, operational decision-making was now more fact-based (less intuition-based) and collaborative. We now discuss these findings in more detail.

Improvements in information quality and scope of GPS implementation in operational decision-making

The three case firms used GPS in a wide range of operational decisions in relation to their vehicles (e.g. position, characteristics, mileage), drivers, routes (e.g. duration, fuel, fueling), loads (e.g. loading/unloading specifications), clients and dealing with possible errors or taking advantage of additional clients in the area of transports (see Table 3 for a detailed description). Informants across cases argued that the use of GPS enhanced information quality and, therefore, improved their decisions across these areas. Specifically, informants highlighted seven key improvements in information quality. First, they argued that the use of GPS improved information timeliness. Data used in the transport process were no longer time-phased (Closs et al., 1997; English, 1999; Forslund, 2007). Second, they noted that information accuracy had also improved as a result of using the GPS (Gorla et al., 2010). Third, informants discussed the benefit of information integration in making operational decisions (Jhingran et al., 2002), which aided the control of costs and route planning. Fourth, informants noted enhanced information availability (Smith \& Simon, 2009). Obtaining information relevant to different decisions was now an easier task. Fifth, the use of GPS improved information generation (Davis \& Golicic, 2010). This helped informants in terms of collecting market information, which was critical for several decisions (e.g. fueling, understanding specific client requirements etc.). Sixth, using the GPS enhanced internal 
information dissemination. Dispatchers in the case firms were now able to disseminate timely information to members of the supply chain (Davis \& Golicic, 2010). Lastly, use of the GPS fostered information visualization; gaining insight into data through visual representation (Ellis \& Dix, 2007).

However, our findings also revealed that the scope of GPS use in different areas of operational decision-making was wider in Firm C, than in Firms A and B (see Table 3). Firms A and B primarily used GPS information for making operational decisions about transport service performance (e.g. position of the vehicle, vehicle characteristics, costs of the driver). Firm B's General Manager, for instance, explained: “We get daily information about fuel consumption, as the system is connected to the engine computer that calculates current vehicle consumption". Yet, Firm C expanded their use of GPS information in operational decisions supporting transport service (such as maintenance, fuel supply, etc.), but also in identifying and catering to client-specific requests. As such, Firm $\mathrm{C}$ further leveraged cost savings in terms of fuel consumption and was able to improve sales through a more customeroriented transport process. A Transport Manager in Firm C noted: "We can plan following fueling periods, as the system gives us the information about quantity of liters in the tank". 
Table 3 Scope of GPS implementation in different operational decisions and improvements in information quality

\begin{tabular}{|c|c|c|c|c|c|c|}
\hline $\begin{array}{l}\text { Use of GPS } \\
\text { information in } \\
\text { different } \\
\text { operational } \\
\text { decisions }\end{array}$ & $\begin{array}{l}\text { Explanation of operational } \\
\text { decisions }\end{array}$ & $\begin{array}{l}\text { Key benefits in } \\
\text { information quality }\end{array}$ & $\begin{array}{l}\text { Potential } \\
\text { performance benefits }\end{array}$ & Firm A & Firm B & Firm C \\
\hline $\begin{array}{l}\text { Position of the } \\
\text { vehicle }\end{array}$ & $\begin{array}{l}\text { Current position of the vehicle } \\
\text { (e.g. } 5 \text { miles West of City Ljubljana, } \\
\text { Side Road Nr. 10) }\end{array}$ & $\begin{array}{l}\text { Information timeliness and } \\
\text { accuracy }\end{array}$ & $\begin{array}{l}\text { Average mileage, } \\
\text { Average sales/km, } \\
\text { Customer satisfaction }\end{array}$ & $\sqrt{ }$ & $\sqrt{ }$ & $\sqrt{ }$ \\
\hline $\begin{array}{l}\text { Vehicle } \\
\text { characteristics } \\
\text { (length, width, } \\
\text { height) }\end{array}$ & $\begin{array}{l}\text { Characteristics of the vehicle, such as } \\
\text { registration plate, length, width, } \\
\text { height } \\
(\text { e.g. Road Train KR 56-88D } \\
(18.75 \mathrm{~m}, 2.55 \mathrm{~m}, 4 \mathrm{~m}))\end{array}$ & $\begin{array}{l}\text { Information integration } \\
\text { and visualization }\end{array}$ & Customer satisfaction & $\sqrt{ }$ & $\sqrt{ }$ & $\sqrt{ }$ \\
\hline $\begin{array}{l}\text { Mileage, duration } \\
\text { of the specific } \\
\text { transport }\end{array}$ & $\begin{array}{l}\text { Mileage and duration of transport } \\
\text { between loading and unloading place } \\
\text { (e.g. Transport Ljubljana-Villach, } \\
\text { Salzburg - Munich }=429 \text { kilometers, } \\
4 \text { driving hours, stop in Villach } 15 \\
\text { minutes) }\end{array}$ & $\begin{array}{l}\text { Information generation and } \\
\text { availability }\end{array}$ & $\begin{array}{l}\text { Customer satisfaction, } \\
\text { Average } \\
\text { sales/month/vehicle, } \\
\text { Average mileage } \\
(\mathrm{km}) / \text { month }\end{array}$ & $\sqrt{ }$ & $\sqrt{ }$ & $\sqrt{ }$ \\
\hline Driver costs & $\begin{array}{l}\text { Estimating costs of the driver based } \\
\text { on: number of kilometers } * € 0,12+ \\
\text { number of loadings/unloadings } * € 11 \\
+ \text { transport during the weekend }(€ 75) \\
+ \text { transport in non EU country }(€ 10)\end{array}$ & $\begin{array}{l}\text { Information integration } \\
\text { and visualization, Internal } \\
\text { information dissemination }\end{array}$ & $\begin{array}{l}\text { Earnings/employee, } \\
\text { EBT }\end{array}$ & $\sqrt{ }$ & $\sqrt{ }$ & $\sqrt{ }$ \\
\hline $\begin{array}{l}\text { Loading and } \\
\text { unloading } \\
\text { specifications }\end{array}$ & $\begin{array}{l}\text { Detailed information about the } \\
\text { loading and unloading places, such } \\
\text { as: loading/unloading address, } \\
\text { shipment number, contact person, } \\
\text { booking times, number of the ramp, } \\
\text { etc. }\end{array}$ & $\begin{array}{l}\text { Information integration } \\
\text { and visualization }\end{array}$ & Customer satisfaction & $\sqrt{ }$ & $\sqrt{ }$ & $\sqrt{ }$ \\
\hline $\begin{array}{l}\text { Costs of fuel, tolls, } \\
\text { etc. }\end{array}$ & $\begin{array}{l}\text { Information about the current price of } \\
\text { the fuel and toll, bridge, tunnel. }\end{array}$ & $\begin{array}{l}\text { Information integration } \\
\text { and visualization }\end{array}$ & EBT, ROA & $\sqrt{ }$ & $\sqrt{ }$ & $\sqrt{ }$ \\
\hline
\end{tabular}




\begin{tabular}{|c|c|c|c|c|c|c|}
\hline $\begin{array}{l}\text { Determining } \\
\text { maintenance work }\end{array}$ & $\begin{array}{l}\text { GPS enables monitoring the planning } \\
\text { of maintenance work for each } \\
\text { vehicle. Maintenance information is } \\
\text { marked per vehicle with the } \\
\text { following colors: Green (maintenance } \\
\text { within } 2 \text { months), Yellow } \\
\text { (maintenance within } 1 \text { month), Red } \\
\text { (maintenance within two weeks). }\end{array}$ & $\begin{array}{l}\text { Internal information } \\
\text { dissemination }\end{array}$ & $\begin{array}{l}\text { Average } \\
\text { sales/month/vehicle, } \\
\text { Average mileage } \\
(\mathrm{km}) / \text { month }\end{array}$ & $\sqrt{ }$ & $\sqrt{ }$ & $\sqrt{ }$ \\
\hline $\begin{array}{l}\text { Time spent on } \\
\text { maintenance }\end{array}$ & $\begin{array}{l}\text { GPS monitors average time spent for } \\
\text { maintenance (e.g. average small } \\
\text { service } 2 \text { hours } 20 \text { minutes, medium } \\
\text { service } 3 \text { hours } 10 \text { minutes and large } \\
\text { service } 5 \text { hours } 30 \text { minutes). The } \\
\text { information is used when planning } \\
\text { transports. }\end{array}$ & $\begin{array}{l}\text { Information generation and } \\
\text { availability }\end{array}$ & $\begin{array}{l}\text { Average } \\
\text { sales/month/vehicle, } \\
\text { Average mileage } \\
(\mathrm{km}) / \text { month }\end{array}$ & $\sqrt{ }$ & & $\sqrt{ }$ \\
\hline Possible errors & $\begin{array}{l}\text { GPS has a warning function } \\
\text { recognizing an error made during the } \\
\text { drive from loading to unloading. } \\
\text { (e.g. Exceeding the driving hours } \\
\text { allowance, not having enough } \\
\text { minutes of short break, driving over } \\
\text { speed limit, etc.). }\end{array}$ & $\begin{array}{l}\text { Information generation and } \\
\text { availability }\end{array}$ & $\begin{array}{l}\text { Customer satisfaction, } \\
\text { Average mileage }\end{array}$ & & $\sqrt{ }$ & $\sqrt{ }$ \\
\hline $\begin{array}{l}\text { Additional clients } \\
\text { in the area of the } \\
\text { transports }\end{array}$ & $\begin{array}{l}\text { The clients are entered in the GPS } \\
\text { and when a vehicle is sent to a certain } \\
\text { destination, the system offers the } \\
\text { dispatcher possible clients that have } \\
\text { loads close to the unloading place. } \\
\text { (e.g. The vehicle is sent to deliver } \\
\text { goods to Hamburg. GPS shows the } \\
\text { clients that have expressed interest in } \\
\text { loads from Hamburg or places around } \\
\text { (within } 150 \text { kilometers) towards } \\
\text { Austria or Slovenia). }\end{array}$ & $\begin{array}{l}\text { Information generation and } \\
\text { availability }\end{array}$ & $\begin{array}{l}\text { Average } \\
\text { sales/month/vehicle, } \\
\text { EBT }\end{array}$ & & & $\sqrt{ }$ \\
\hline Average weight & $\begin{array}{l}\text { GPS enables monitoring the weight } \\
\text { of the loads of all vehicles towards }\end{array}$ & $\begin{array}{l}\text { Information generation and } \\
\text { availability }\end{array}$ & EBT, ROA & & & $\sqrt{ }$ \\
\hline
\end{tabular}




\begin{tabular}{|c|c|c|c|c|}
\hline & $\begin{array}{l}\text { different destinations. This helps the } \\
\text { dispatcher to plan the transport in } \\
\text { certain countries where there are } \\
\text { special limitations regarding the } \\
\text { weight of the vehicle. } \\
\text { (e.g. In Europe the total weight of the } \\
\text { vehicle including the goods must not } \\
\text { exceed the } 40 \text { tons). }\end{array}$ & & & \\
\hline $\begin{array}{l}\text { Liters of fuel in the } \\
\text { tanks and vehicle } \\
\text { fueling periods } \\
\text { Time spent for } \\
\text { fueling }\end{array}$ & $\begin{array}{l}\text { Current level of fuel in the tank, } \\
\text { average consumption of the vehicle } \\
\text { and average fuelling time on the gas } \\
\text { station. } \\
\text { (e.g. Vehicle KR 56-88D ( } 345 \text { liters; } \\
\text { weekly consumption } 32,7 \text { liters/100 } \\
\text { kilometers; average } 20 \text { minutes } \\
\text { fuelling period)). }\end{array}$ & $\begin{array}{l}\text { Information generation and } \\
\text { availability, Information } \\
\text { timeliness and accuracy, } \\
\text { Internal information } \\
\text { dissemination }\end{array}$ & $\begin{array}{l}\text { EBT, ROA, Average } \\
\text { sales/month/vehicle, } \\
\text { Average } \\
\text { sales/kilometer }\end{array}$ & $\sqrt{ }$ \\
\hline $\begin{array}{l}\text { Client-specific } \\
\text { information }\end{array}$ & $\begin{array}{l}\text { GPS enables entering specific } \\
\text { information about the client, such as: } \\
\text { working time, type of goods, contact } \\
\text { person, change of the pallets and } \\
\text { other material, etc. }\end{array}$ & $\begin{array}{l}\text { Information generation and } \\
\text { availability, Information } \\
\text { timeliness and accuracy }\end{array}$ & $\begin{array}{l}\text { Customer satisfaction, } \\
\text { Average } \\
\text { sales/kilometer, } \\
\text { Average } \\
\text { sales/month/vehicle }\end{array}$ & $\sqrt{ }$ \\
\hline
\end{tabular}

Source: Interview transcripts 


\section{Fact-based and Collaborative decision-making}

Increased use of GPS information endorsed fact-based operational decision-making. Rationality in decision-making reflects the degree to which a decision maker relies on consideration of relevant facts in making decisions (Low \& Mohr, 2001). Decision makers who are less rational tend not to see the need to use much information; they rely on their own intuition (Low \& Mohr, 2001; Citroen, 2011). The case data revealed that decision-making before GPS adoption was less rational and more intuitive. An informant explained: "With no current information about the position of the vehicle from the GPS, we did not know for sure where the vehicle was when the client called us. We estimated the unloading time, according to previous experience but not according to any actual information that we had" (Dispatcher Firm A). Another elaborated: "For sure the price was calculated based on our feeling of what the client would accept. We knew the competition and therefore we estimated how low the price for a specific destination could go. The real calculation was hardly ever made" (General Manager, Firm C). This had implications in terms of uncertainty around costs and quotes, and often influenced efficiency negatively in the transport process.

Yet, all firms proposed that with GPS adoption, the availability of new, accurate, reliable and on-time information helped transport firms to introduce decisions based on facts, rather than purely on assumptions and intuition (Watson et al., 2004; Hvolby \& Steger-Jensen, 2010). This was mostly evident in Firm C (see summarized evidence in Table 4). The use of GPS information on transport, variable costs, fuel consumption, etc. made Firm C's decision-making more fact-based. However, some intuitive assumptions still informed their decisions. As a General Manager in Firm C explained: "We sometimes change the decision about price, when we have a feeling that the market price by competition would be lower". And a Dispatcher added: "If we believe that the client is important for expanding our business we could lower the price for the transport to a specific destination". In contrast, in Firms A and B the increasing use of facts in their decision-making after GPS adoption was not as pervasive as in Firm C. Informants in both firms argued that on average around 20-30\% of operational decisions were still influenced by assumptions, because of lack of information about fuel costs on specific routes, availability of transports and clients on specific destinations, and so forth. 
Table 4 Facts vs. intuition driving decision-making before and after GPS adoption

\begin{tabular}{|c|c|c|c|c|c|c|}
\hline & \multicolumn{2}{|c|}{$\begin{array}{c}\text { Firm A } \\
\text { Moderate performer }\end{array}$} & \multicolumn{2}{|c|}{$\begin{array}{c}\text { Firm B } \\
\text { Moderate performer }\end{array}$} & \multicolumn{2}{|c|}{$\begin{array}{c}\text { Firm C } \\
\text { Strong performer }\end{array}$} \\
\hline & Before GPS adoption & After GPS adoption & Before GPS adoption & After GPS adoption & Before GPS adoption & After GPS adoption \\
\hline $\begin{array}{l}\% \text { of fact-based } \\
\text { decisions }{ }^{1}\end{array}$ & $30 \%-40 \%$ & $70 \%-80 \%$ & $45 \%-55 \%$ & $75 \%-80 \%$ & $35 \%-45 \%$ & $90 \%-95 \%$ \\
\hline $\begin{array}{l}\% \text { of intuition-based } \\
\text { decisions }{ }^{1}\end{array}$ & $60 \%-70 \%$ & $20 \%-30 \%$ & $45 \%-55 \%$ & $20 \%-25 \%$ & $55 \%-65 \%$ & $5 \%-10 \%$ \\
\hline \multicolumn{7}{|l|}{ Decisions } \\
\hline $\begin{array}{l}\text { Knowing the situation } \\
\text { on the market } \\
\text { (The flow of goods; The } \\
\text { estimate of the imports and } \\
\text { exports to and from } \\
\text { Slovenia; The situation in } \\
\text { the transport industry) }\end{array}$ & Intuition & Intuition & Intuition & Intuition & Intuition & Intuition \\
\hline $\begin{array}{l}\text { Importance of the client } \\
\text { for the firm } \\
\text { (The relationship with the } \\
\text { client: years of cooperation, } \\
\text { number of transports in one } \\
\text { month, destination of the } \\
\text { transports, quality of } \\
\text { cooperation, payment } \\
\text { terms) }\end{array}$ & Intuition & Intuition & Intuition & Intuition & Intuition & Intuition \\
\hline $\begin{array}{l}\text { Client order } \\
\text { (Information about: } \\
\text { loading/unloading time and } \\
\text { address, goods, customs } \\
\text { clearance, price of the } \\
\text { transport, etc.) }\end{array}$ & Intuition & Intuition & Intuition & Intuition & Intuition & Intuition \\
\hline $\begin{array}{l}\text { The duration of the } \\
\text { transport in hours } \\
\text { (Planned time for the } \\
\text { specific transport to be } \\
\text { made, or the time between } \\
\text { the loading and unloading } \\
\text { place) }\end{array}$ & Intuition & Fact & Intuition & Fact & Intuition & Fact \\
\hline Toll costs & Intuition & Fact & Intuition & Fact & Intuition & Fact \\
\hline Fuel costs & Intuition & Intuition & Intuition & Intuition & Intuition & Fact \\
\hline
\end{tabular}




\begin{tabular}{|c|c|c|c|c|c|c|}
\hline Driver costs & Intuition & Fact & Intuition & Fact & Intuition & Fact \\
\hline $\begin{array}{l}\text { Vehicle closest to the } \\
\text { loading place } \\
\text { (Information about position } \\
\text { of the closest vehicle to the } \\
\text { loading place of the planned } \\
\text { transport) }\end{array}$ & Intuition & Intuition & Intuition & Fact & Intuition & Fact \\
\hline $\begin{array}{l}\text { Clients close to the } \\
\text { unloading place } \\
\text { (The clients are entered in } \\
\text { the GPS and when a vehicle } \\
\text { is sent to a certain } \\
\text { destination, the system } \\
\text { offers the dispatcher } \\
\text { possible clients that have } \\
\text { loads close to the unloading } \\
\text { place) }\end{array}$ & Intuition & Fact & Intuition & Fact & Intuition & Fact \\
\hline $\begin{array}{l}\text { Quality of the road } \\
\text { (The roads in different } \\
\text { countries are marked and } \\
\text { grouped in motorways, } \\
\text { highways, side roads, etc. } \\
\text { The dispatcher can obtain } \\
\text { through GPS a digital } \\
\text { camera view (through } \\
\text { Google Maps) which shows } \\
\text { the quality of the road) }\end{array}$ & Fact & Fact & Intuition & Fact & Intuition & Fact \\
\hline Illustrative Quotes & $\begin{array}{l}\text { "The dispatchers, who work } \\
\text { with clients on a daily basis, } \\
\text { knew what the market and our } \\
\text { competition could offer. If the } \\
\text { transport was important for us } \\
\text { we lowered the price by } 20 \text { or } \\
50 \text { Euro, however we never did } \\
\text { a precise calculation, what the } \\
\text { price means for us." (General } \\
\text { Manager) }\end{array}$ & $\begin{array}{l}\text { "The company has a formula } \\
\text { for calculating price which } \\
\text { includes the following } \\
\text { information from the GPS: } \\
\text { mileage, duration of the } \\
\text { transport, price of toll and fuel } \\
\text { and costs of the driver. The } \\
\text { price averagely deviates from } \\
\text { the accepted market price in } \\
\text { short distances between } 15 \% \\
\text { and } 25 \% \text { and long (over } 2500 \\
\text { km) distances between } 5 \% \text { and } \\
7 \% . " \text { (Observation notes) }\end{array}$ & $\begin{array}{l}\text { "We had some rough } \\
\text { estimation; however, how } \\
\text { the competitive firms } \\
\text { behave was crucial for } \\
\text { us". (Dispatcher) }\end{array}$ & $\begin{array}{l}\text { "We have a strategic } \\
\text { client for which we } \\
\text { propose yearly prices for } \\
\text { all destinations. The } \\
\text { starting point is the price } \\
\text { from the last year, which } \\
\text { is recalculated and then } \\
\text { negotiated. How low we } \\
\text { can go with the price } \\
\text { depends on the quantity } \\
\text { of the transports and on } \\
\text { the situation on the } \\
\text { market." (General } \\
\text { Manager) }\end{array}$ & $\begin{array}{l}\text { "We estimated the } \\
\text { variable costs and we } \\
\text { knew that the price must } \\
\text { cover this number". } \\
\text { (Dispatcher) }\end{array}$ & $\begin{array}{l}\text { "We now calculate our } \\
\text { internal cost price. We add } \\
\text { the margin and correct it } \\
\text { according to the importance } \\
\text { of the client. The price is } \\
\text { finally intuitively adjusted } \\
\text { according to the market } \\
\text { trends. In most cases this is } \\
\text { the final price. It is very } \\
\text { precise and for this reason } \\
\text { we do not have an alternative } \\
\text { solution in case the price } \\
\text { would not be accepted." } \\
\text { (Logistics Manager) }\end{array}$ \\
\hline
\end{tabular}

${ }^{1}$ Estimates provided by the case informants during interviews 
Source: Interview transcripts 
Moreover, wide use of GPS-enabled information endorsed more collaborative decision-making. Collaborative relationships refer to communication, trust, and interdependence among firms in the supply chain; these have been found to reduce uncertainty and risk in the decision-making process (Wu \& Chuang, 2010). Our findings suggested that the more widely the case firms used GPS information, the more they established collaborative decision-making among supply chain partners (e.g. transport firm, maintenance firm, supplier of the fuel, client), resulting in added benefits for all involved partners. Across the cases, informants stressed that key information from the GPS, such as the position of the vehicle, vehicle characteristics (length, width, height), mileage, duration of the specific transport and loading and unloading specifications, was pivotal in resolving questions among supply chain partners about the duration of the transport, monthly capacity needed, possible loading/unloading days, type of goods delivered, etc.

Before GPS adoption, in all three firms, collaboration in decision-making with supply chain partners was limited. On the contrary, collaborative decision-making flourished after GPS adoption. Detailed descriptions are available in Table 5. 
Table 5 Collaboration in decision-making before and after GPS adoption

\begin{tabular}{l|l|l} 
Firm A & Firm B & Firm C
\end{tabular}

\begin{tabular}{|c|c|c|c|c|c|c|}
\hline \multirow{2}{*}{\multicolumn{7}{|c|}{\begin{tabular}{l|l} 
Firm A \\
Involvement of external partner in collaborative decision-making
\end{tabular}}} \\
\hline & & & & & & \\
\hline & Before GPS adoption & After GPS adoption & Before GPS adoption & After GPS adoption & Before GPS adoption & After GPS adoption \\
\hline $\begin{array}{l}\text { Client } \\
\text { (Firm or individual who } \\
\text { places the order with the } \\
\text { transport service) }\end{array}$ & $\sqrt{ }$ & $\sqrt{ }$ & $\sqrt{ }$ & $\sqrt{ }$ & $\sqrt{ }$ & $\sqrt{ }$ \\
\hline $\begin{array}{l}\text { Maintenance firm } \\
\text { (responsible for the main } \\
\text { maintenance work of the } \\
\text { vehicles) }\end{array}$ & & $\sqrt{ }$ & & & & $\sqrt{ }$ \\
\hline $\begin{array}{l}\text { Supplier of the fuel } \\
\text { (supplies the transport firm } \\
\text { with the fuel) }\end{array}$ & & & & $\sqrt{ }$ & & $\sqrt{ }$ \\
\hline \multicolumn{7}{|c|}{ Areas of collaborative decision-making } \\
\hline $\begin{array}{l}\text { Transport characteristics } \\
\text { (e.g. Information about } \\
\text { loading/unloading time and } \\
\text { address, information about } \\
\text { goods and other specific } \\
\text { information such as customs } \\
\text { clearance, etc.) }\end{array}$ & $\sqrt{ }$ & $\sqrt{ }$ & $\sqrt{ }$ & $\sqrt{ }$ & $\sqrt{ }$ & $\sqrt{ }$ \\
\hline $\begin{array}{l}\text { Duration of the transport } \\
\text { (Planned time for the specific } \\
\text { transport to be made, or the } \\
\text { time between the loading and } \\
\text { unloading place. For example: } \\
\text { from Ljubljana to Frankfurt is } \\
820 \text { kilometers, the driver } \\
\text { therefore needs } 10 \text { hours and } \\
30 \text { minutes of driving time. } \\
\text { Following EU regulations if } \\
\text { the driver starts at } 8 \mathrm{am}, \mathrm{s} / \mathrm{he} \\
\text { should arrive to Frankfurt } \\
\text { around } 10 \text { am the next day } \\
\text { (10 hours and } 30 \text { minutes of } \\
\text { drive, two pauses for } 45 \\
\text { minutes and one long } 9 \mathrm{~h} \\
\text { pause). }\end{array}$ & $\sqrt{ }$ & $\sqrt{ }$ & $\sqrt{ }$ & $\sqrt{ }$ & $\sqrt{ }$ & $\sqrt{ }$ \\
\hline
\end{tabular}




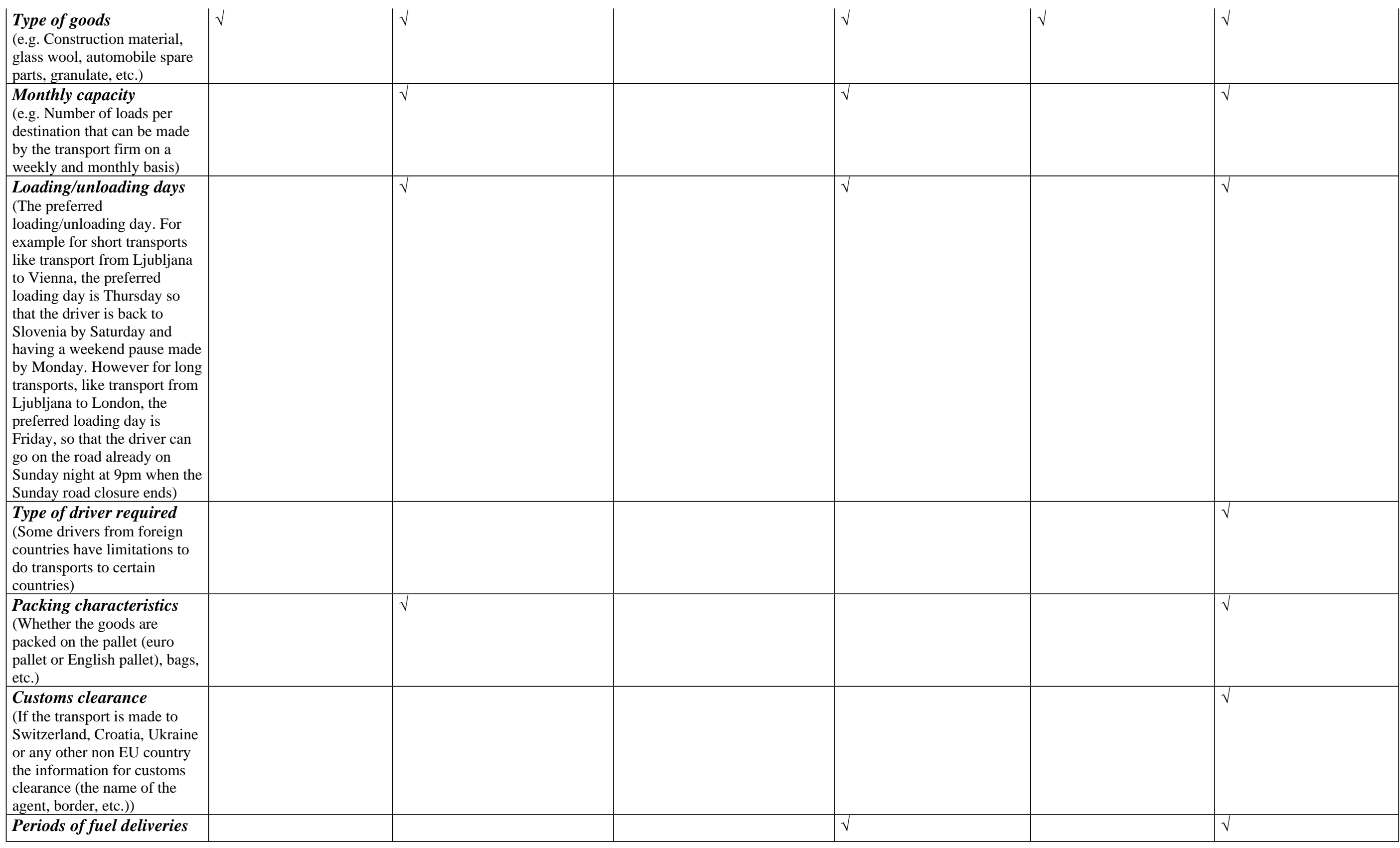




\begin{tabular}{|c|c|c|c|c|c|c|}
\hline $\begin{array}{l}\text { (Information about previous } \\
\text { and planned fuel deliveries) }\end{array}$ & & & & & & \\
\hline $\begin{array}{l}\text { Maintenance planning } \\
\text { (Information about previous } \\
\text { and planned maintenance } \\
\text { work) }\end{array}$ & & & & & & $\sqrt{ }$ \\
\hline Illustrative Quotes & $\begin{array}{l}\text { "We communicated with } \\
\text { the client when we } \\
\text { received an order about } \\
\text { details of loading and } \\
\text { unloading times and } \\
\text { peculiarities that we } \\
\text { should consider; and at } \\
\text { the end, when we } \\
\text { informed the client that } \\
\text { the transport is } \\
\text { completed." (Dispatcher) }\end{array}$ & $\begin{array}{l}\text { "Before we sign the contract } \\
\text { we set the standards about the } \\
\text { delivery days. If the duration of } \\
\text { the transport is more than } 5 \\
\text { days and delivery is not in the } \\
\text { same week we leave the option } \\
\text { to the transport firm to set the } \\
\text { unloading day itself. However, } \\
\text { this information must be } \\
\text { passed to us before the loading } \\
\text { day, so that we can arrange the } \\
\text { unloading with the receiver of } \\
\text { the goods." (Client) }\end{array}$ & $\begin{array}{l}\text { "We did not know exactly } \\
\text { where the vehicles were at a } \\
\text { certain time. We passed this } \\
\text { information to the client only } \\
\text { when the driver called us." } \\
\text { (Dispatcher) }\end{array}$ & $\begin{array}{l}\text { "The transport firm gives } \\
\text { us each year the } \\
\text { information when it is best } \\
\text { for them to come to our } \\
\text { warehouse for loading. } \\
\text { Usually this is based on } \\
\text { their experience of past } \\
\text { transports. We then fix the } \\
\text { day and arrange our } \\
\text { production regarding this } \\
\text { agreement." (Client) }\end{array}$ & $\begin{array}{l}\text { "The planning of further } \\
\text { maintenance was really } \\
\text { hard. We did not know } \\
\text { the position of the } \\
\text { vehicle, hence we could } \\
\text { not inform the } \\
\text { maintenance firm when } \\
\text { the vehicle will be in the } \\
\text { workshop." (General } \\
\text { Manager) }\end{array}$ & $\begin{array}{l}\text { "When we decide to } \\
\text { cooperate with the } \\
\text { transport firm on a long } \\
\text { run, we require from } \\
\text { them the information } \\
\text { about the length, width } \\
\text { and height of the } \\
\text { vehicles. Then we decide } \\
\text { together which packaging } \\
\text { and loading method } \\
\text { would be best according } \\
\text { to the available options." } \\
\text { (Client) }\end{array}$ \\
\hline
\end{tabular}

Source: Interview transcripts 
Informants from Firms $\mathrm{A}$ and $\mathrm{B}$ mainly discussed how decision-making was transformed in relation to collaborating with their clients and operational efficiency. A Dispatcher from Firm A explained the situation before GPS adoption: "After we received an order, it was our decision how to plan and perform the transport, as long as we were on time at the loading/unloading place". The firm could not change the loading or unloading days, while the client was not supported with sufficient information on why this was the case. Transport information from the GPS enabled these transport firms to promptly inform their clients about the position of vehicles and any changes that happened or were about to happen during the transport service. A Logistics Manager from Firm B noted: "If anything unplanned happens on the road, we immediately inform the client". A Dispatcher from Firm A reinforced this point: "We then together decide what is best to do, to change the route or the loading/unloading times". It was evident that the clients also positively received this change towards a more collaborative decision-making approach. For instance, a client of Firm B elaborated: "Before, we just asked the transport firm about the price and the feasibility of a specific transport. However, we never elaborated how it will be performed". Pre-GPS adoption, the partners were distant and only the transport firm drove decisions about transport performance. A client of Firm A noted: "We used to set the loading day on Friday, not knowing that in this case the driver needs to drive over the weekend". On the contrary, postGPS adoption the transport firm was able to provide clients with information (such as mileage, duration of the transport), collaborate on planning monthly capacity, possible loading and unloading days, and estimating the duration of the transport. "We now together set the best loading day and frequency of transports, so that the transport firm does not have unnecessary costs and that it is suitable for our production plan" (Client, Firm A). Informants across cases noted that this resulted in substantial cost savings for all partners, improved customer satisfaction and increased sales for the transport firms.

However, Firm $\mathrm{C}$ adopted a more balanced orientation. They expanded the use of information for operational decision-making also in planning maintenance works and managing fuel deliveries. They used information such as: (1) average weight, (2) vehicle fueling periods, (3) time spent for fueling, and (4) time spent for maintenance, for collaboratively organizing maintenance works with the maintenance firm and fuel deliveries with the fuel supplier. Before GPS adoption, lack of information about the position of the vehicles and time spent for maintenance hardened the transport firm's maintenance planning. 
The General Manager of Firm C explained: "Before the GPS implementation we did not know the estimated time for the vehicle to arrive to the maintenance shop. The workers in the maintenance shop had other vehicles to check. Therefore, our drivers each time waited for at least two hours". The Dispatcher could now constantly monitor the vehicle and was able to plan the maintenance works in advance. A Dispatcher from Firm C elaborated: "At the day of sending the vehicle to the maintenance shop we inform them when exactly the vehicle will be there, we decide together whether the proposed time should be changed... As a result, we can plan further transports for the driver and the maintenance shop knows exactly when to expect the vehicle. It is much easier for both partners".

Table 6 provides a summary of the benefits for the three transport firms, their clients, their fuel suppliers and maintenance firms from the shift towards more collaborative decision-making following GPS adoption.

Table 6 Benefits of collaborative decision-making after GPS adoption

\begin{tabular}{|c|c|c|c|}
\hline Benefits & $\begin{array}{c}\text { Firm A } \\
\text { Client Orientation }\end{array}$ & $\begin{array}{c}\text { Firm B } \\
\text { Operational Efficiency } \\
\text { Orientation }\end{array}$ & $\begin{array}{c}\text { Firm C } \\
\text { Balanced Orientation }\end{array}$ \\
\hline \multicolumn{4}{|l|}{ Transport firm } \\
\hline Loading day on a week day & $\sqrt{ }$ & $\sqrt{ }$ & $\sqrt{ }$ \\
\hline $\begin{array}{l}\text { Mutual acceptance of the } \\
\text { packing and loading procedures }\end{array}$ & & & $\sqrt{ }$ \\
\hline $\begin{array}{l}\text { Fuel delivery is planned 3-4 days } \\
\text { in advance }\end{array}$ & & $\sqrt{ }$ & $\sqrt{ }$ \\
\hline $\begin{array}{l}\text { Fuel supply is always above } \\
\text { required level }\end{array}$ & & $\sqrt{ }$ & $\sqrt{ }$ \\
\hline $\begin{array}{l}\text { Maintenance is planned one } \\
\text { week in advance }\end{array}$ & & & $\sqrt{ }$ \\
\hline $\begin{array}{l}\text { The client can set up the } \\
\text { unloading day }\end{array}$ & $\sqrt{ }$ & & $\sqrt{ }$ \\
\hline \multicolumn{4}{|l|}{ Client } \\
\hline Better planning & $\sqrt{ }$ & $\sqrt{ }$ & $\sqrt{ }$ \\
\hline $\begin{array}{l}\text { Planning of the loadings on a } \\
\text { week day }\end{array}$ & $\sqrt{ }$ & $\sqrt{ }$ & $\sqrt{ }$ \\
\hline $\begin{array}{l}\text { Mutual acceptance of the } \\
\text { packing and loading procedures }\end{array}$ & $\sqrt{ }$ & & $\sqrt{ }$ \\
\hline $\begin{array}{l}\text { More goods packaged and loaded } \\
\text { on one vehicle }\end{array}$ & $\sqrt{ }$ & & $\sqrt{ }$ \\
\hline $\begin{array}{l}\text { Simplified procedure of customs } \\
\text { clearance }\end{array}$ & & & $\sqrt{ }$ \\
\hline \multicolumn{4}{|l|}{ Fuel supplier } \\
\hline Pre-arranged fuel deliveries & & $\sqrt{ }$ & $\sqrt{ }$ \\
\hline \multicolumn{4}{|l|}{ Maintenance firm } \\
\hline Pre-arranged maintenance works & & & $\sqrt{ }$ \\
\hline
\end{tabular}




\begin{tabular}{|l|l|l|l|}
\hline & $\begin{array}{l}\text { "Whis year we } \\
\text { "With one of our largest } \\
\text { clients we agreed that they } \\
\text { will arrange the delivery in } \\
\text { a way that our drivers do } \\
\text { not need to drive over the } \\
\text { weekend. This saved us a } \\
\text { Illustrative Quotes }\end{array}$ & $\begin{array}{l}\text { "Our transport firm } \\
\text { gives } \text { us the time of } \\
\text { vehicle arrival two days } \\
\text { in advance, so } \\
\text { according to that } \\
\text { information we can } \\
\text { arrange the } \\
\text { monthly required } \\
\text { capacity of the } \\
\text { transports that the } \\
\text { transport firm needs to } \\
\text { deliver. The } \\
\text { information that the } \\
\text { transport firm passed } \\
\text { to us was very } \\
\text { helpful." (Client) }\end{array}$ \\
\hline
\end{tabular}

Source: Interview transcripts

Overall, findings in relation to RQ1 illustrated that increased use of GPS information in more areas of decision-making, enhanced information quality and endorsed fact-based and collaborative decision-making among supply chain partners (e.g. transport firm, maintenance firm, supplier of the fuel, client), resulting in added benefits for all supply chain partners. Therefore, we argue that:

Proposition 1: Increased use of GPS-enabled information endorses fact-based and collaborative decision-making.

Exploring the underlying mechanisms that link GPS-enabled information to improvements in firm performance

Turning our attention to our second research question, we then investigated the link between GPS-enabled information in operational decision-making and firm performance. Due to space limitations, we provide our analysis on firm performance before and after GPS adoption for the three case firms in our supplementary online Appendix. Based on this analysis, we classified Firm $\mathrm{C}$ as the strong performer in our sample. Firm A performed relatively better than Firm B, so we classified Firm A as the moderate performer and Firm B as the weak performer within our sample (note, however, that both Firms A and B exhibited better performance across various indicators than the industry average).

We explored the differences amongst the three case firms, particularly in terms of the use of GPS-enabled information in their operational decision-making, which may have contributed to the variation in firm performance post-GPS adoption in our sample. At first glance, our data suggested that Firm C, the case firm that exhibited wider use of GPS information in their operational decision-making (see Table 3), was associated with better 
firm performance. Wider use of GPS information improved information quality and enabled more fact-based (see Table 4) and collaborative (see Table 5) decision-making in Firm C, compared to Firms A and B. Managers as well as Dispatchers in Firm C argued that the move towards more fact-based and collaborative decision-making in the transport process was an important contributor to the firm's growth. The General Manager in Firm C explained: "Now we can reroute more vehicles in one week". A Dispatcher added: "We can save time on loading and unloading, while the bookings are already agreed together with the client". A Transport Manager concluded: "Generally we can earn more with one vehicle, due to better routing and direct savings during transport execution". Moreover, Firm C's clients not only benefited from the availability of up-to-date information about the transport service. They also saw a dramatic improvement in managing urgent loads and coping with non-predictive changes. A Firm C client elaborated: "We can plan the production, as we have up-to-date information when the vehicle will be at our place". Another two clients added: "Workers in the warehouse can plan the work and we cut overtime hours by 20\%" ... "Compared to what we used to do, our cooperation is now much more simplified, with less phone contacts. We are very happy for that". Firms A and B were not leveraging these benefits to the same degree. According to a Dispatcher in firm A, "we can do more in the same time; however, we still need sometimes to contact the driver via cell phone, which also requires some time from us". A Logistics Manager in Firm B also claimed: "In some cases we were too expensive, hence we had to lower the price. The first transports were given to the competition". And a Dispatcher in Firm B added: "At first we were overloaded with all this new information and this was confusing for us". The more fact-based and collaborative decision-making in Firm C, therefore, appeared to positively affect the firm's performance. Fact-based operational decision-making in terms of planning the transport, estimating costs, managing the client, even understanding the market, enabled Firm $C$ to achieve greater cost reductions, further boost sales and improve relationships with supply partners. At the same time, the GPS equipped the trading partners with up-to-date and reliable information about the transports. This allowed them to efficiently and effectively coordinate and plan for current and future transports. Operational decision-making was, thus, transformed into a collaborative act with the trading partners in an effort to achieve common goals (Wu \& Chuang, 2010). Such collaborative decision-making resulted in benefits for all trading partners, including reduced supply chain costs, better planning and better communication, coordination and integration in 
the supply chain. Overall, informants from Firm C associated their improved performance to the wide scope of implementation and use of the GPS in their operational decision-making. We, therefore, propose that:

Proposition 2: Wider scope of implementation and use of GPS in operational decision-making facilitates firm performance.

However, a closer look at the data (see Tables 3, 4, and 5) highlighted that the breadth of the implementation and use of GPS in operational decision-making in Firms A and B was quite similar. Yet, Firm A exhibited better performance than Firm B post-GPS adoption. Drawing on critics, who claim that firms only enjoy differential performance when ICT is combined with capabilities that drive comparative advantage (Clemons \& Row, 1991; Mithas et al., 2011) and is endorsed by other organizational factors (Oh \& Pinsonneault, 2007; McLaren et al., 2011), we delved deeper within our cases to gain richer explanations of factors that may have influenced differential performance from GPS adoption in our sample. Our investigation surfaced some interesting insights. The three case firms differed in their information management capability (see Table 7 for detailed description), but also in organizational factors such as top management support, project management, financial support for the project, end-user involvement, rewarding, training and employee resistance (see Table 8 for detailed description). 


\section{Table 7 Firm Differences in Information Management Capability}

\begin{tabular}{|c|c|c|c|}
\hline & $\begin{array}{l}\text { Firm A } \\
\text { Moderate Performer }\end{array}$ & $\begin{array}{l}\text { Firm B } \\
\text { Weak Performer }\end{array}$ & $\begin{array}{l}\text { Firm C } \\
\text { Strong Performer }\end{array}$ \\
\hline $\begin{array}{l}\text { Availability of } \\
\text { quality information } \\
\text { for decision-making }\end{array}$ & $\begin{array}{l}\text { GPS provides } \\
\text { appropriate levels of } \\
\text { accurate, timely, reliable, } \\
\text { secure, and confidential } \\
\text { information. }\end{array}$ & $\begin{array}{l}\text { GPS provides appropriate } \\
\text { levels of accurate, timely, } \\
\text { reliable, secure, and } \\
\text { confidential information. }\end{array}$ & $\begin{array}{l}\text { GPS provides appropriate } \\
\text { levels of accurate, timely, } \\
\text { reliable, secure, and } \\
\text { confidential information. } \\
\text { Information is more visual } \\
\text { and comprehensive. }\end{array}$ \\
\hline $\begin{array}{l}\text { Software tools for } \\
\text { connectivity } \\
\text { and access to } \\
\text { information }\end{array}$ & $\begin{array}{l}\text { Adequate software tools } \\
\text { for connectivity and } \\
\text { access to information are } \\
\text { available. } \\
\text { Information about the } \\
\text { transport service is } \\
\text { directly emailed to the } \\
\text { customer via GPS at } \\
\text { certain times. }\end{array}$ & $\begin{array}{l}\text { Adequate software tools } \\
\text { for connectivity and access } \\
\text { to information are } \\
\text { available. } \\
\text { The firm has two types of } \\
\text { customers. "Strategic" } \\
\text { customers receive the } \\
\text { information about the } \\
\text { transport service through } \\
\text { direct access to GPS. } \\
\text { Other, "less strategic" } \\
\text { customers receive the } \\
\text { information about the } \\
\text { transport service via } \\
\text { phone. }\end{array}$ & $\begin{array}{l}\text { Adequate software tools } \\
\text { for connectivity and access } \\
\text { to information are } \\
\text { available. } \\
\text { Customers receive } \\
\text { information about the } \\
\text { transport service through } \\
\text { direct access to GPS. }\end{array}$ \\
\hline $\begin{array}{l}\text { IT systems } \\
\text { integration after } \\
\text { GPS adoption }\end{array}$ & $\begin{array}{l}\text { IT systems integration } \\
\text { was manually handled. } \\
\text { End-users cooperated } \\
\text { during the integration. }\end{array}$ & $\begin{array}{l}\text { IT systems integration was } \\
\text { manually handled. }\end{array}$ & $\begin{array}{l}\text { Full integration of GPS } \\
\text { and transactional system. }\end{array}$ \\
\hline $\begin{array}{l}\text { Adaptability of the } \\
\text { infrastructure to } \\
\text { emerging business } \\
\text { needs }\end{array}$ & $\begin{array}{l}\text { Standard features of the } \\
\text { GPS. }\end{array}$ & $\begin{array}{l}\text { Standard features of the } \\
\text { GPS. }\end{array}$ & $\begin{array}{l}\text { Available additional online } \\
\text { features of the GPS: } \\
\text { - Fuel monitoring sensor } \\
\text { connected with GPS } \\
\text { - Digital tachograph } \\
\text { connected with GPS }\end{array}$ \\
\hline
\end{tabular}

Source: Interview transcripts 


\section{Table 8 Firm Differences in Organizational Factors}

\begin{tabular}{|c|c|c|c|}
\hline $\begin{array}{l}\text { Top management } \\
\text { support }\end{array}$ & $\begin{array}{l}\text { Project was partially } \\
\text { supported by top } \\
\text { management. } \\
\text { "We knew that we } \\
\text { needed the system, that } \\
\text { was the reason why we } \\
\text { implemented it, however } \\
\text { I still believe that we } \\
\text { could function also } \\
\text { without it." } \\
\text { (General Manager) }\end{array}$ & $\begin{array}{l}\text { Project was partially } \\
\text { supported by top } \\
\text { management. } \\
\text { "Current operation } \\
\text { functioned well, we did not } \\
\text { have complaints or } \\
\text { reclamations. From this } \\
\text { point of view this was not } \\
\text { the reason for GPS } \\
\text { adoption." } \\
\text { (General Manager) }\end{array}$ & $\begin{array}{l}\text { Project was fully } \\
\text { supported by top } \\
\text { management. } \\
\text { "We increased sales each } \\
\text { year. We believed that the } \\
\text { GPS will add also in future } \\
\text { growth in sales." } \\
\text { (General Manager) }\end{array}$ \\
\hline $\begin{array}{l}\text { Project management } \\
\text { (Planning and } \\
\text { managing the } \\
\text { project) }\end{array}$ & $\begin{array}{l}\text { Planning of the project } \\
\text { was included in the } \\
\text { implementation phase. } \\
\text { The quality assurance } \\
\text { manager was informally } \\
\text { the project manager, who } \\
\text { planned, controlled and } \\
\text { managed the project. } \\
\text { "We saw the system } \\
\text { within one of our } \\
\text { partners. We then } \\
\text { contacted their GPS } \\
\text { supplier, and then we } \\
\text { arranged the meeting, } \\
\text { where the system was } \\
\text { presented to us. Later the } \\
\text { supplier arranged } \\
\text { everything for the } \\
\text { installations of the } \\
\text { devices." } \\
\text { (General Manager) }\end{array}$ & $\begin{array}{l}\text { There was no special } \\
\text { planning and management } \\
\text { of the project. The general } \\
\text { manager was in charge of } \\
\text { the whole project. The } \\
\text { supplier of the GPS was } \\
\text { the informal leader of the } \\
\text { project. (Observation } \\
\text { notes) }\end{array}$ & $\begin{array}{l}\text { Before the start of the } \\
\text { project, the project group } \\
\text { prepared the project } \\
\text { description and investment } \\
\text { plan in which also the } \\
\text { project time-plan was } \\
\text { presented. The project } \\
\text { group was also responsible } \\
\text { for managing and } \\
\text { monitoring the project. It } \\
\text { reported to the General } \\
\text { Manager about the results } \\
\text { and its performance. } \\
\text { "The plan and description } \\
\text { of all project phases was } \\
\text { also presented verbally } \\
\text { and in written form to us in } \\
\text { the transport department." } \\
\text { (Dispatcher) }\end{array}$ \\
\hline $\begin{array}{l}\text { Financial support } \\
\text { for the project }\end{array}$ & $\begin{array}{l}\text { A budget was not } \\
\text { allocated and the firm } \\
\text { had limited financial } \\
\text { capabilities. } \\
\text { "We had a limited } \\
\text { amount of money to } \\
\text { spend on this. In the } \\
\text { same year we bought the } \\
\text { land for a new logistics } \\
\text { centre, which was our } \\
\text { investment priority." } \\
\text { (General Manager) }\end{array}$ & $\begin{array}{l}\text { The budget allocated was } \\
\text { limited, however it was } \\
\text { included in the yearly } \\
\text { planning. } \\
\text { "We included this } \\
\text { investment into our yearly } \\
\text { investment plan. However, } \\
\text { we limited it at around } \\
\text { €35,000; anything more } \\
\text { than that we would not be } \\
\text { able to pay." } \\
\text { (General Manager) }\end{array}$ & $\begin{array}{l}\text { The budget allocated was } \\
\text { large enough and was } \\
\text { included in the yearly } \\
\text { planning. } \\
\text { "We planned the budget } \\
\text { for GPS adoption, which } \\
\text { was not exceeded by the } \\
\text { end of the project." } \\
\text { (Transport Manager) }\end{array}$ \\
\hline $\begin{array}{l}\text { End-user } \\
\text { involvement }\end{array}$ & $\begin{array}{l}\text { End-users (dispatchers, } \\
\text { drivers) were involved in } \\
\text { the GPS adoption from } \\
\text { the start of the project. } \\
\text { They actively cooperated } \\
\text { during the installation }\end{array}$ & $\begin{array}{l}\text { The general manager } \\
\text { together with the GPS } \\
\text { supplier firstly installed } \\
\text { the system, but at the } \\
\text { beginning it was } \\
\text { inaccessible to other }\end{array}$ & $\begin{array}{l}\text { The project group } \\
\text { organized periodical } \\
\text { meetings where end-users } \\
\text { where informed about } \\
\text { changes. End-users } \\
\text { actively cooperated in }\end{array}$ \\
\hline
\end{tabular}




\begin{tabular}{|c|c|c|c|}
\hline & $\begin{array}{l}\text { phase and asked about } \\
\text { the adjustments that } \\
\text { needed to be done to } \\
\text { optimize operation. They } \\
\text { accepted the system } \\
\text { pretty quickly. }\end{array}$ & $\begin{array}{l}\text { dispatchers. They then } \\
\text { fine-tuned it and then } \\
\text { informed others how to use } \\
\text { it. End-users were } \\
\text { educated and later } \\
\text { constantly monitored by } \\
\text { the general manager. }\end{array}$ & $\begin{array}{l}\text { optimizing GPS operation } \\
\text { and functionalities. }\end{array}$ \\
\hline Rewarding scheme & $\begin{array}{l}\text { Data from the GPS were } \\
\text { used to encourage the } \\
\text { drivers to improve their } \\
\text { performance. } \\
\text { Data from the GPS were } \\
\text { used for wage } \\
\text { calculations and as part } \\
\text { of the rewarding } \\
\text { strategy. } \\
\text { "Measures of current } \\
\text { rewarding system: } \\
\text { number of hours in the } \\
\text { office, job position, } \\
\text { responsibilities, sick } \\
\text { leave."(Employment } \\
\text { Relations Policy) }\end{array}$ & $\begin{array}{l}\text { Data from the GPS were } \\
\text { used to encourage the } \\
\text { drivers to improve their } \\
\text { performance. }\end{array}$ & $\begin{array}{l}\text { Data from the GPS were } \\
\text { used to encourage the } \\
\text { drivers to improve their } \\
\text { performance. } \\
\text { Data from the GPS were } \\
\text { used for wage calculations } \\
\text { and as part of the } \\
\text { rewarding strategy. } \\
\text { "With the use of GPS we } \\
\text { were finally able to tell } \\
\text { employees that their } \\
\text { salaries depend on them." } \\
\text { (Transport Manager) }\end{array}$ \\
\hline Training & $\begin{array}{l}\text { End-users received } \\
\text { general training and } \\
\text { education on the use of } \\
\text { the GPS. } \\
\text { "The budget for training } \\
\text { and education was very } \\
\text { limited; therefore I tried } \\
\text { to give an overview of } \\
\text { the system. I explained } \\
\text { what was needed to my } \\
\text { colleagues." } \\
\text { (Logistics Manager) }\end{array}$ & $\begin{array}{l}\text { End-users received general } \\
\text { training and support on } \\
\text { how to use the GPS. } \\
\text { Training was seen as an } \\
\text { unnecessary cost. } \\
\text { "The implementation of } \\
\text { the GPS was very costly, } \\
\text { hence we did not decide to } \\
\text { have any special training. } \\
\text { The handbooks were } \\
\text { handed to us by the } \\
\text { supplier." } \\
\text { (General Manager) }\end{array}$ & $\begin{array}{l}\text { End-users received } \\
\text { advanced training and } \\
\text { support on how to use the } \\
\text { GPS following a special } \\
\text { training plan. Training was } \\
\text { seen as an advantage. } \\
\text { Training contract was } \\
\text { stipulated with the } \\
\text { supplier. } \\
\text { "We were asked to help } \\
\text { the drivers while they were } \\
\text { in the vehicle." } \\
\text { (Dispatcher) }\end{array}$ \\
\hline $\begin{array}{l}\text { Employee resistance } \\
\text { towards GPS use }\end{array}$ & $\begin{array}{l}\text { The firm had minor } \\
\text { problems with employee } \\
\text { resistance towards GPS } \\
\text { use. } \\
\text { "We have one driver that } \\
\text { simply refused to use the } \\
\text { GPS. For communication } \\
\text { he still uses just his cell } \\
\text { phone." } \\
\text { (Dispatcher) }\end{array}$ & $\begin{array}{l}\text { The firm had major } \\
\text { problems with employee } \\
\text { resistance towards GPS } \\
\text { use. } \\
\text { "For some of the drivers } \\
\text { we needed months so that } \\
\text { they learn how to send the } \\
\text { message. They received the } \\
\text { message on the GPS } \\
\text { system and sent a reply } \\
\text { back from their cell phone. } \\
\text { We had real chaos and at } \\
\text { some point we could not } \\
\text { solve the problem." } \\
\text { (General Manager) }\end{array}$ & $\begin{array}{l}\text { The firm had no problems } \\
\text { with employee resistance } \\
\text { towards GPS use. } \\
\text { "Drivers did not believe in } \\
\text { the first instance that this } \\
\text { will simplify their work, } \\
\text { however we managed to } \\
\text { show them the positive } \\
\text { contributions". } \\
\text { (Transport Manager) }\end{array}$ \\
\hline
\end{tabular}


Source: Interview transcripts

To begin with, Firm $\mathrm{C}$ appeared to have the information management capability in place to mobilize best use of GPS-enabled information and enjoy the performance benefits. In particular, compared to Firms $\mathrm{A}$ and $\mathrm{B}$, Firm $\mathrm{C}$ worked on the full integration of their GPS and with their transactional system, including positions of the vehicles, times of the transports, stops, border crossings, time spent in different countries, fuelling, etc. The General Manager of Firm C noted: "We managed to establish the transfer of all information from the GPS to our transactional information system from the start of GPS functioning. At first we had a few problems, which were resolved with our IT support immediately”. Firm C also leveraged online features to enhance information quality on additional decision areas (for example, on fuel consumption). Firm A, however, appeared to make better use of software tools for connectivity and access to information than Firm B.

Moreover, organizational factors seem to have facilitated better use of GPS or inhibited its benefits amongst the case firms. In Firm C, for instance, the GPS adoption project was fully supported by top management and careful project planning and management was in place. The firm knew from the start what kind of information was needed, when and how this information should be visually presented and how this information should be shared among stakeholders (departments, clients, etc.). The GPS adoption project was skilfully led by a project group and was given appropriate financial and training support. The project group prepared a description of GPS adoption and investment plan, which included a time-plan with required changes and actions. A Dispatcher in Firm C recalled: "The plan and description of all project phases was also presented verbally and in written form to us in the transport department". The adoption of the GPS brought about many changes in communication for dispatchers, drivers and administrators in the case firms. Leaders in Firm C, along with the project group and the supplier of the GPS, organized relevant training on how to communicate via the GPS and utilize its benefits. Training took place on an ongoing basis. In addition, in Firm C, effective GPS adoption was also linked to revised rewards to further motivate staff. Monthly sales by vehicle, monthly number of orders entered by the dispatchers and monthly earnings by vehicle, were amongst the measures that were incorporated in performance reviews. A Transport Manager in Firm C 
argued: "With the use of GPS we were finally able to show employees that their salaries depend on them”.

On the other hand, the adoption of the GPS in Firms A and B was somehow more of an ad-hoc decision, as a reaction to changes in the market. Yet, in Firm A, end-users were in involved in the adoption process from the start of the GPS implementation project (compared to Firm B where end-users got involved much later in the process). Users in Firm A quickly started to apply the GPS-enabled information and were not under too much stress and close supervision by the top management. The quality assurance manager helped end-users to adjust their daily tasks and operations. The adjustment phase was, as a result, quite short. On the contrary, in Firm B, the general manager was in charge of the entire project. She implemented the GPS initially along with the GPS supplier in isolation from the end-users (dispatchers, drivers). End-users were only informed about the changes when the GPS was already in operation. Firm B put in place some basic training, but still faced major problems with employees resisting the use of the GPS. It seemed that post-GPS adoption, drivers suddenly became more 'visible'. The dispatchers were able to see in detail their times, roads taken, stops, as well as all mistakes and errors that the drivers made. Drivers, therefore, initially believed that GPS was adopted only to control them and increase their workloads. Sticking to pre-GPS routines or even hampering the system, were some of the forms of resistance that were exhibited in Firm B.

Overall, our findings indicate that information management capability (in terms of availability of quality information in decision-making, software tools for connectivity and access to information, IT systems integration post-GPS adoption and adaptability of the infrastructure to emerging business needs) along with organizational factors (such as top management support, project management of GPS implementation, financial support, enduser involvement, rewarding, training and employee resistance) facilitated better use of GPSenabled information in operational decision-making and, thus, enhanced firm performance. We, therefore, argue that:

Proposition 3: Information management capability and organizational factors moderate the relationship between GPS-enabled information and firm performance. 


\section{Discussion}

We contribute to the business value of IT literature by unpacking how the use of GPSenabled information changes operational decision-making and enables firms to earn abovenormal returns (see Figure 1 below).

\section{Figure 1 Conceptual Framework}

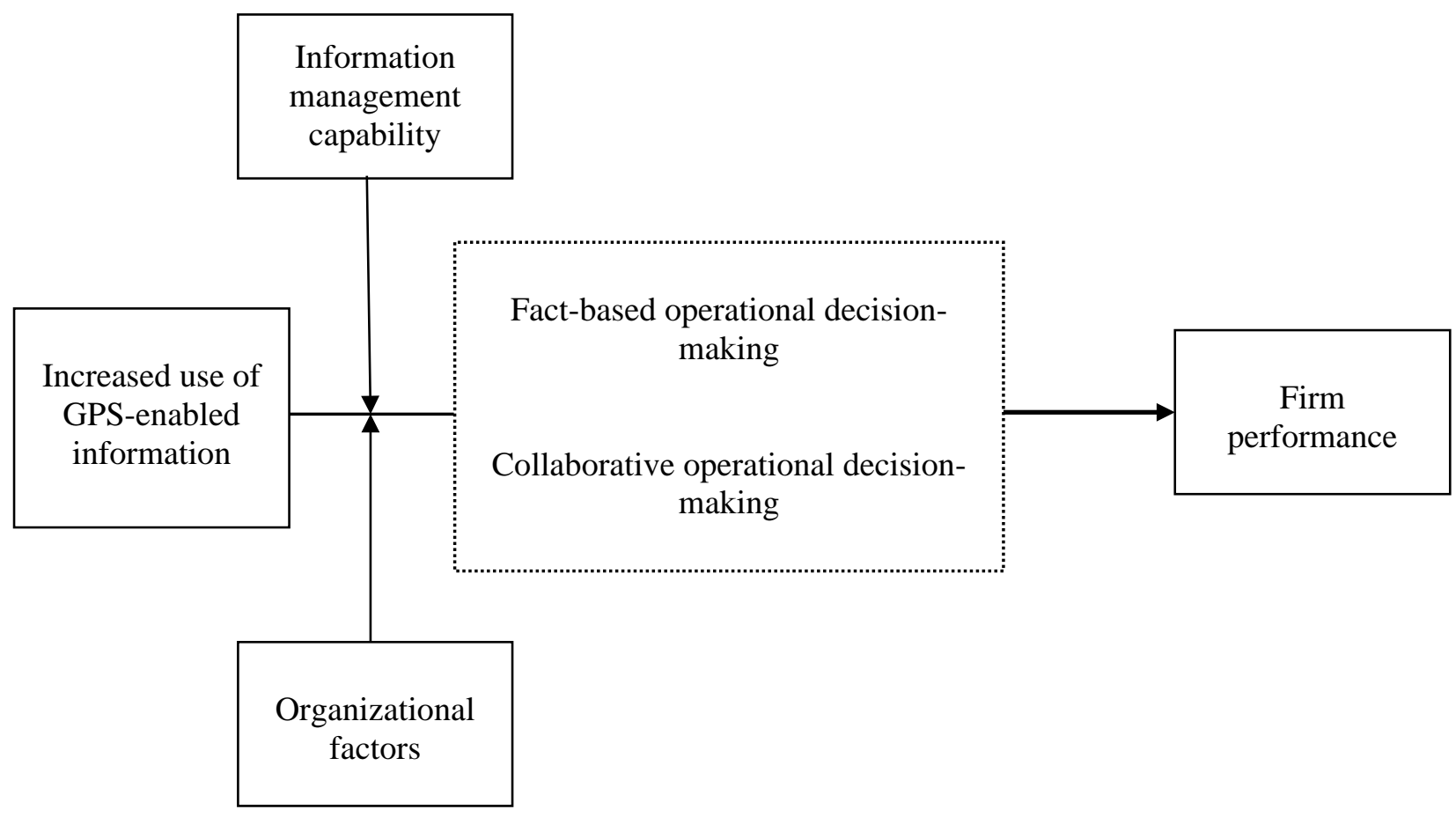

Consistent with our theoretical foundations in decision-making and resource-based perspectives, our study makes three theoretical contributions. First, we show that increased use of GPS-enabled information can enhance information quality and make operational decision-making more fact-based and collaborative. The shift towards fact-based decisionmaking enables decision makers to use information in considering more alternatives when making operational decisions (Priem et al., 1995; Citroen, 2011). It involves tasks such as searching for information on potential alternatives, examining positive and negative consequences of different alternatives, defining the procedure for following up the decision, etc. (Citroen, 2011). Echoing extant studies in decision-making literature, we find that when decision-makers use more GPS-enabled information, they accelerate the decision-making process, better forecast the decision-making time horizon (Citroen, 2011) and reduce the 
number of organizational levels involved in authorizing the proposed decision (Huber, 1990). Increased use of GPS-enabled information also triggers a shift towards more collaborative decision-making within the supply chain (among the transport firm, client, maintenance firm etc.). As a result, supply chain partners realize operational process benefits in the form of cost reductions, better transport and maintenance planning, lower inventory levels, better organization of the workforce and no fuel shortages, while they leverage improvements in process integration and customer service (Barratt, 2004; Li \& Lin, 2006). As such, GPSenabled information does not only empower firms to automate and informate, but more importantly to transform information quality and operational decision-making in supply chain relationships (Zuboff, 1988).

Second, drawing on resource-based logic (Ray et al., 2005), we argue that such transformations in operational decision-making, driven by increased use of GPS-enabled information, can foster differential performance impacts (Priem et al., 1995; Hvolby \& Steger-Jensen, 2010). However, we warn scholars and practitioners that a firm's information management capability (in terms of availability of quality information in decision-making, software tools for connectivity and access to information, IT systems integration post-GPS adoption and adaptability of the infrastructure to emerging business needs) and organizational factors (such as such as top management support, project management of GPS implementation, financial support, end-user involvement, rewarding, training and employee resistance) can facilitate (or inhibit) effective use of GPS-enabled information in operational decision-making and, thus, moderate differential performance benefits of GPS adoption. As such, we extend business value of IT literature, which argues that seeking strategic advantage solely by developing IT competency may not necessarily realize enhanced performance; information management capability is an important moderator (Tippins \& Sohi, 2003; Davis \& Golicic, 2010; Mithas et al., 2011). We also extend literature that views organizational factors as critical for effective IT adoption (Leung, 2001; Nah et al., 2001; Hong \& Kim, 2002; Dezdar \& Sulaiman, 2011).

Our results should be interpreted with caution, as it is not possible to completely rule out alternative explanations. An alternative explanation for the performance differences across the three case firms could be differences in firm size. Although all three firms were classified as medium-sized, Firm C (the stronger performer) was the largest in our sample. One could suggest that it had a larger system scope for implementation, and, hence, that size 
drove the enhanced use of GPS-enabled information. Yet, on the flipside, we could also argue that the larger system size could have made it more challenging to implement GPS adoption and leverage the operational benefits of systems integration. In either case, firm size did not emerge as an alternative explanation through our qualitative findings. One could also claim that firm age, the industry sector and location of the firms could have influenced our results. We, therefore, recommend that future studies control for firm size, age, industry sector and location to account for performance differences attributable to organizational resources, interindustry or country differences (Hendricks \& Singhal, 2001).

Our case study design also limits our ability to generalize our results to a wider population of firms. Thus, we recommend that scholars replicate and extend this study to wider contexts. For instance, we should underline that the deep change often required for leveraging transformational benefits from the adoption of IS can be a costly and risky process (Besson \& Rowe, 2012). In our study, all three firms were profitable and exhibited better performance across various indicators than the industry average. Therefore, perhaps the context of the three firms was not that risky when it came to GPS adoption. Further research should study how GPS or other IS adoption influences operational decision making in lowerperforming firms and also explore the associated costs and risks. Furthermore, studying failure cases will add valuable insights (Besson \& Rowe, 2012). In addition, a longitudinal design would be desirable to further examine the causal dynamics of the relationships outlined in our conceptual framework. Moreover, further research should delve deeper on the mechanisms that foster IT capability building. Data-driven operational decision-making is only one piece of the puzzle in achieving differential performance returns. Future research should extend our work and examine how other elements such as firm structure, people and routines interact with IT in enabling differential performance returns.

Our results also highlight important managerial implications. To begin with, we recommend increased use of GPS-enabled information in operational decision-making, as this can facilitate cost reductions, improve vehicle and dispatcher productivity, foster supply chain cooperation and enhance customer satisfaction. However, we highlight that since GPS is readily available and, thus, not rare or hard to imitate, investing in this ICT per se is unlikely to yield differential performance returns against competitors. Instead, the performance impact is conditional upon the firm's capability of utilizing GPS-enabled data to improve information quality and engage in fact-based and collaborative operational decision- 
making. We, therefore, recommend that firms also pay attention to their information management capability and the organizational factors outlined in our findings, as these will facilitate better use of GPS-enabled information in operational decisions and will boost process benefits and performance returns. For instance, firms have to enforce formal data and process integration embedded in IT infrastructure, but also foster informal integration through active IT business collaboration within the supply chain. Leaders can also play a pivotal role, by championing the adoption of GPS, offering ongoing training and support, and by revising the rewarding schemes to motivate and engage staff in this process.

\section{Conclusion}

Information is a vital resource for managers amidst environments high in uncertainty. This study explored how the use of GPS-enabled information transforms operational decisionmaking and highlighted its link with firm performance. Leveraging comparative case studies and blending decision-making and business value of IT literature facilitated the development of research propositions and a conceptual framework that explicate these relationships. We hope that this study will spark future attempts to elaborate our findings. 


\section{References}

ATA UZ and TOKER A (2012) The effect of customer relationship management adoption in business-to-business markets. The Journal of Business \& Industrial Marketing 27(6), 497-507.

BARRATT M (2004) Understanding the meaning of collaboration in the supply chain. Supply Chain Management 9(1), 30-42.

BESSON P and ROWE F (2012) Strategizing information systems-enabled organizational transformation: A transdisciplinary review and new directions. Journal of Strategic Information Systems 21(2), 103-124.

Benbasat I, DeXter AS, DRURY DH and Goldstein RC (1984) A critique of the stage hypothesis: Theory and empirical evidence. Communications of the ACM 27(5), 476485.

BHARADWAJ AS (2000) A resource-based perspective on information technology capability and firm performance: An empirical investigation. MIS Quarterly 24(1), 169-196.

BRYNJOLFSSON E (1993) The productivity paradox of information technology. Communications of the ACM 36(12), 66-77.

BRYNJOLFSSON E and HITT LM (1996) Productivity, business profitability, and consumer surplus: Three different measures of information technology value. MIS Quarterly 20(2), 121-142.

CARBONARA N (2005) Information and communication technology and geographical clusters: Opportunities and spread. Technovation 25(3), 213-222.

CASSELl C and SYMON G (1994) Qualitative methods in organizational research: A practical guide. Sage Publications, London.

Citroen CL (2011) The role of information in strategic decision-making. International Journal of Information Management 31(6), 493-501.

Clemons E and Row M (1991) Sustaining IT advantage: The role of structural differences. MIS Quarterly 15(1), 275-292.

Closs D, GoldBSy T and Clinton S (1997) Information technology influences on world class logistics capability. International Journal of Physical Distribution and Logistics Management 27(1), 4-17.

CRAINIC TG (2000) Service network design in freight transportation. European Journal of Operational Research 122(2), 272-288.

DAVENPORT T (1993) Process innovation: Reengineering work through information technology. Harvard Business School Press, Boston, MA.

DAVENPORT TH and BEERS MC (1995) Managing information about processes. Journal of Management Information Systems 12(1), 57.

DAVIS DF and GoliCIC SL (2010) Gaining comparative advantage in supply chain relationships: The mediating role of market-oriented IT competence. Journal of the Academy of Marketing Science 38(1), 56-70.

DEDRICK J, GURBAXANI V and KRAEMER KL (2003) Information technology and economic performance: A critical review of the empirical evidence. ACM Computing Surveys 35(1), 1-28.

DEVARAJ S and KOHLI R (2000) Information technology payoff in the health-care industry: A longitudinal study. Journal of Management Information Systems 16(4), 41-67.

DEZDAR S and SUlAimAN A (2011) The influence of organizational factors on successful ERP implementation. Management Decision 49(6), 911-926. 
EISENHARDT K (1989) Building theories from case study research. Academy of Management Review 14(4), 532-550.

ELLIS G and DIX A (2007) A taxonomy of clutter reduction for information visualisation. IEEE Transactions on Visualization and Computer Graphics 13(6), 1216-1223.

ENG T-Y (2004) The role of e-marketplaces in supply chain management. Industrial Marketing Management 33(2), 97-105.

ENG T-Y (2006) Mobile supply chain management: Challenges for implementation. Technovation 26(5-6), 682-686.

ENGLISH LP (1999) Improving data warehouse and business information quality: Methods for reducing costs and increasing profits. John Wiley \& Sons, Inc. New York, NY.

EPPLER MJ (2006) Managing information quality: Increasing the value of information in knowledge-intensive products and processes. Springer, Heidelberg/New York, NY.

EPPLER MJ, HELFERT M and GASSER U (2004) Information quality: Organizational, technological, and legal perspectives. Studies in Communication Sciences 4(2), 1-16.

FERNELEY E and BEN L (2006) Secondary user relations in emerging mobile computing environments. European Journal of Information Systems 15(3), 301-301-306.

FiRESTONE W and HERRIOTT R (1983) The formalization of qualitative research: An adaptation of "soft" science to the policy world. Evaluation Review 7(4), 437-466.

Fleischmann B, GNUTZMAnN S and ElKe S (2004) Dynamic vehicle routing based on online traffic information. Transportation Science 38(4), 420-433.

FORSLUND H (2007) Measuring information quality in the order fulfilment process. International Journal of Quality \& Reliability Management 24(5), 515-524.

Forster N (1994) The analysis of company documentation. C. Cassell, G. Symon, eds. Qualitative Methods in Organizational Research. Sage Publications, Thousand Oaks, CA.

GendREAU M, LAPORTE G and SEMET F (2004) Heuristics and lower bounds for the bin packing problem with conflicts. Computers and Operations Research 31(3), 347-358.

GHODSYPOUR S and O'BRIEN C (2001) The total cost of logistics in supplier selection, under conditions of multiple sourcing, multiple criteria and capacity constraint. International Journal of Production Economics 73(1), 15-28.

GIANNOPOULOS GA (2004) The application of information and communication technologies in transport. European Journal of Operational Research 152(2), 302-320.

GLASER B and StRAuSS A (1967) The discovery of grounded theory. Aldine de Gruyter, New York, NY.

GORLA N, SOMERS TM and WONG B (2010) Organizational impact of system quality, information quality, and service quality. The Journal of Strategic Information Systems 19(3), 207-228.

HENDRICKS KB and SINGHAL VR (2001) Firm characteristics, total quality management and financial performance. Journal of Operations Management 19, 269-285.

HONG K-K and KIM Y-G (2002) The critical success factors for ERP implementation: An organizational fit perspective. Information \& Management 40(1), 25-40.

HUBER GP (1990) A theory of the effects of advanced information technologies on organizational design, intelligence, and decision making. Academy of Management Review 15(1), 47-71.

Hvolby H-H and Steger-Jensen K (2010) Technical and industrial issues of Advanced Planning and Scheduling (APS) systems. Computers in Industry 61(9), 845-851. 
JHINGRAN AD, MAtTos N and PiRAHESh H (2002) Information integration: A research agenda. IBM Systems Journal 41(4), 555-562.

KARIMI J, SOMERS TM and BHATTACHERJEE A (2007) The impact of ERP implementation on business process outcomes: A factor-based study. Journal of Management Information Systems 24(1), 101-134.

KetTinger WJ and LEE CC (1994) Perceived service quality and user satisfaction with the information services function. Decision Sciences 25(5/6), 737-766.

KOHLI R and DeVARAJ S (2003) Measuring information technology payoff: A meta-analysis of structural variables in firm-level empirical research. Information Systems Research $14(2), 127-145$.

KoHLi R and GROVER V (2008) Business value of IT: An essay on expanding research directions to keep up with the times. Journal of the Association for Information Systems 9(1), 23-39.

KORHONEN-SANDE S (2010) Micro-foundations of market orientation: Influencing nonmarketing managers' customer information processing. Industrial Marketing Management 39(4), 661-671.

KRAEMER KL and DutTON WH (1979) The interests served by technological reform: The case of computing. Administration and Society 11(1), 80-106.

LEUNG H (2001) Organizational factors for successful management of software development. The Journal of Computer Information Systems 42(2), 26-37.

Li S and LIN B (2006) Accessing information sharing and information quality in supply chain management. Decision Support Systems 42(3), 1641-1656.

Li T, VAN HECK E and VERVEST P (2009) Information capability and value creation strategy: Advancing revenue management through mobile ticketing technologies. European Journal of Information Systems 18(1), 38-51.

LILLRANK P (2003) The quality of information. International Journal of Quality and Reliability Management 20(6-7), 691-703.

LIU C and ARNETT KP (2000) Exploring the factors associated with web site success in the context of electronic commerce. Information \& Management 38(1), 23-33.

LOW GS and MOHR JJ (2001) Factors affecting the use of information in the evaluation of marketing communications productivity. Journal of the Academy of Marketing Science 29(1), 70-88.

LU Y and RAMAMURTHY K (2011) Understanding the link between information technology capability and organizational agility: An empirical examination. MIS Quarterly 35(4), 931-954.

Marchet G, Perego A and Perotti S (2009) An exploratory study of ICT adoption in the Italian freight transportation industry. International Journal of Physical Distribution \& Logistics Management 39(9), 785-812.

McDonald F, Warhurst S and ALlen M (2008) Autonomy, embeddedness, and the performance of foreign owned subsidiaries. Multinational Business Review 16(3), 7392.

MCLAREN TS, HEAD MM, YUAN Y and CHAN YE (2011) A multilevel model for measuring fit between a firm's competitive strategies and information systems capabilities. MIS Quarterly 35(4), 909-929.

Melville N, KRAEMER K and GuRBAXANi V (2004) Information technology and organizational performance: An integrative model of IT business value. MIS Quarterly 28(2), 283-322. 
Miles M and Huberman A (1994) Qualitative data analysis: An expanded sourcebook. Sage Publications, Thousand Oaks, CA.

Mintsis G, Basbas S, Papaioannou P, Taxiltaris C and Tziavos IN (2004) Applications of GPS technology in the land transportation system. European Journal of Operational Research 152(2), 399-409.

MITHAS S, KRISHNAN MS and FORNELL C (2008) Effect of information technology investments on customer satisfaction: Theory and evidence. Rochester, NY.

Mithas S, Ramasubbu N and Sambamurthy V (2011) How information management capability influences firm performance. MIS Quarterly 35(1), 237-256.

MOORMAN C (1995) Organizational market information processes: Cultural antecedents and new product outcomes. Journal of Marketing Research 32(3), 318-335.

Morgan A, Colebourne D and ThOMAs B (2006) The development of ICT advisors for SME businesses: An innovative approach. Technovation 26(8), 980-987.

MUKHOPADHYAY T and KEKRE S (2002) Strategic and operational benefits of electronic integration in B2B procurement processes. Management Science 48(10), 1301-1313.

MuKHOPADHYAY T, RAJIV S and SRINIVASAN K (1997) Information technology impact on process output and quality. Management Science 43(12), 1645-1659.

NAH F, LAU J and KuANG J (2001) Critical factors for successful implementation of enterprise systems. Business Process Management Journal 7(3), 285-296.

$\mathrm{OH} \mathrm{W}$ and PINSONNEAULT A (2007) On the assessment of the strategic value of information technologies: Conceptual and analytical approaches. MIS Quarterly 31(2), 239-265.

PARSSIAN A (2006) Managerial decision support with knowledge of accuracy and completeness of the relational aggregate functions. Decision Support Systems 42(3), 1494-1502.

PAUlRAJ A and CHEN I (2007) Strategic buyer-supplier relationships, information technology and external logistics integration. Journal of Supply Chain Management 43(2), 2-14.

Petter S, Delone W and MCLEAN E (2008) Measuring information systems success: Models, dimensions, measures, and interrelationships. European Journal of Information Systems 17(3), 236-263.

Popovič A, Hackney R, COElHo PS and JAKlič J (2012) Towards business intelligence systems success: Effects of maturity and culture on analytical decision making. Decision Support Systems 54(1), 729-739.

PRIEM RL, RASHEED AMA and KOTULIC AG (1995) Rationality in strategic decision processes, environmental dynamism and firm performance. Journal of Management 21(5), 913-929.

RAi A, PATNAYAKUni R and SeTH N (2006) Firm performance impacts of digitally enabled supply chain integration capabilities. MIS Quarterly 30(2), 225-246.

RAY G, MUHANNA WA and BARNEY JB (2005) Information technology and the performance of the customer service process: A resource-based analysis. MIS Quarterly 29(4), 625-652.

Repoussis PP, PARASKeVopoulos DC, Zobolas G, TARANTILIS CD and IoANNOU G (2009) A web-based decision support system for waste lube oils collection and recycling. European Journal of Operational Research 195(3), 676-700.

RuŽEVIČIUS J and GEDMINAITĖ A (2007) Business information quality and its assessment. Engineering Economics 52(2), 18-25. 
RYSSEL R, RITTER T and GEMÜNDEN HG (2004) The impact of information technology deployment on trust, commitment and value creation in business relationships. Journal of Business and Industrial Marketing 19(3), 197-207.

SAncheZ-Rodrigues S, Stantchev D, Potter A, Naim M and Whiteing A (2008) Establishing a transport operation focused uncertainty model for the supply chain. International Journal of Physical Distribution \& Logistics Management 38(5), 388411.

SANCHEZ-Rodrigues V, PotTer A and NAIM M (2010a) Evaluating the causes of uncertainty in logistics operations. International Journal of Logistics Management 21(1), 45-64.

SANCHEZ-Rodrigues V, POTTER A and NAIM M (2010b) The impact of logistics uncertainty on sustainable transport operations. International Journal of Physical Distribution \& Logistics Management 40(1/2), 61-83.

SCHÖNBERGER J (2010) Adaptive demand peak management in online transport process planning. OR Spectrum 32(3), 831-859.

SMITH B and SimON M (2009) How data integration systems affect strategic decision making in small firms. Journal of Small Business Strategy 20(1), 35-51.

Souchon AL, CAdogan JW, Procter DB and DewSNAP B (2004) Marketing information use and organisational performance: The mediating role of responsiveness. Journal of Strategic Marketing 12(4), 231-242.

Souchon AL, Diamantopoulos A, Holzmüller HH, Axinn CN, Sinkula JM, Simmet H and DURDEN GR (2003) Export information use: A five-country investigation of key determinants. Journal of International Marketing 11(3), 106-127.

TAMBE P, HitT LM and BRYNJOLFSSON E (2012) The extroverted firm: How external information practices affect innovation and productivity. Management Science 58(5), 843-859.

TIPPINS MJ and SOHI RS (2003) IT competency and firm performance: Is organizational learning a missing link? Strategic Management Journal 24(8), 745-761.

TRACEY M, VONDEREMBSE MA and LIM JS (1999) Manufacturing technology and strategy formulation: Keys to enhancing competitiveness and improving performance. Journal of Operations Management 17(4), 411-428.

VAN DER VORST JGAJ and BEULENS AJM (2002) Identifying sources of uncertainty to generate supply chain redesign strategies. International Journal of Physical Distribution \& Logistics Management 32(6), 409-430.

VAn Der Vorst JGAJ, Beulens AJM, De Wit W and Van BeeK P (1998) Supply chain management in food chains: Improving performance by reducing uncertainty. International Transactions in Operational Research 5(6), 487-499.

VANDENBOSCH B and HufF SL (1997) Searching and scanning: How executives obtain information from executive information systems. MIS Quarterly 21(1), 81-107.

VuKŠIĆ VB, BACH MP and POPOVIČ A (2013) Supporting performance management with business process management and business intelligence: A case analysis of integration and orchestration. International Journal of Information Management 33(4), 613-619.

WATSON HJ, Fuller C and ARIYACHANDRA T (2004) Data warehouse governance: Best practices at blue cross and blue shield of North Carolina. Decision Support Systems $38(3), 435-450$. 
White JC, VARADARAJAN PR and DACIN PA (2003) Market situation interpretation and response: The role of cognitive style, organizational culture, and information use. Journal of Marketing 67(3), 63-79.

WU F, MAHAJAN V and BALASUBRAMANIAN S (2003) An analysis of e-business adoption and its impact on business performance. Journal of the Academy of Marketing Science 31(4), 425-447.

Wu I-L and ChUANG C-H (2010) Examining the diffusion of electronic supply chain management with external antecedents and firm performance: A multi-stage analysis. Decision Support Systems 50(1), 103-115.

YIN R (1994) Case study research: Design and methods. Sage Publications, Thousand Oaks, CA.

YIN R (2003) Applications of case study research. Sage Publications, Thousand Oaks, CA.

Zuboff S (1988) In the Age of the Smart Machine: The Future of Work and Power. Basic Books, New York, NY.

\section{Acknowledgements}

The authors would like to thank the Special Issue Editors, Professors Rajeev Sharma, Sunil Mithas and Atreyi Kankanhalli, the Editor, Professor Frantz Rowe and the anonymous reviewers for their invaluable feedback and suggestions. 